Historic, archived document

Do not assume content reflects current scientific knowledge, policies, or practices. 



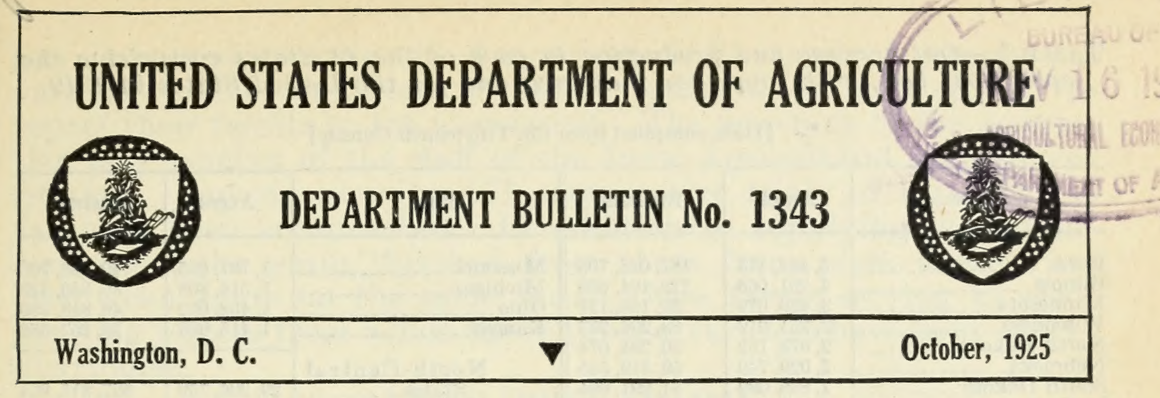

\section{IMPROVED OAT VARIETIES FOR THE CORN BELT}

By L. C. Bunnetr, Chief in Cereal Breeding, Iowa Agricultural Experiment Station, and Agent, Office of Cereal Investigations, Bureau of Plant Industry; and T. R. Stanton, Agronomist in Charge of Oat Investigations, and C. W. Warburton, formerly Agronomist in Charge of Cereal Agronomy Investigations, Office of Cereal Investigations, Bureau of Plant Industry

\begin{tabular}{|c|c|c|}
\hline \multicolumn{3}{|c|}{ CONTENTS } \\
\hline Page & & Page \\
\hline 1 & Iowar & - \\
\hline 2 & $\begin{array}{l}\text { History and description } \\
\text { Yields of Iowar }\end{array}$ & \\
\hline 3 & Ratio of grain to straw & 1 \\
\hline 3 & Rate-of-seeding experiments & 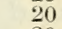 \\
\hline $\begin{array}{l}5 \\
9\end{array}$ & Iogren ${ }_{\text {History and description }}$ & 20 \\
\hline 9 & Yields of Iogren & 21 \\
\hline 10 & Rate-of-seeding experiments & 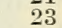 \\
\hline 10 & Yields of other varieties at the & \\
\hline 11 & $\begin{array}{l}\text { Iowa station, } \\
\text { Yields of Albion, Richland, and Iowar }\end{array}$ & \\
\hline 13 & oats outside of Iowa & \\
\hline & & \\
\hline
\end{tabular}

\section{INTRODUCTION}

Oats are grown over much of the United States, but the greater portion of the crop is produced in a belt extending westward from New York to North Dakota and south to the latitude of the Ohio River. From Ohio westward this area coincides very largely with the Corn Belt, and it is in this belt that the greater part of the oat crop is produced. This is shown by the data presented in Table 1, which gives the oat acreage and production for the 12 North-Central States in 1919. In that year these 12 States contained three-fourths ${ }^{\circ}$ of the total acreage and produced nearly four-fifths of the total crop of the United States.

In the Corn Belt oats are exceeded in importance only by corn. This importance is due primarily to the fact that the oat is the most satisfactory intermediate crop to grow between corn and wheat or between corn and grass in those rotations which long practice has shown to be the most profitable in this area. 
TABLE 1.-Oat acreage and production in each of the 12 States comprising the spring-oat belt, with totals for that area and for the United States in 1919

[Data compiled from the Thirteenth Census]

\begin{tabular}{|c|c|c|c|c|c|}
\hline State & Acres & Bushels & State & Acres & Bushels \\
\hline Iowa & $5,484,113$ & $187,045,705$ & Missouri & $1,707,055$ & $40,493,700$ \\
\hline Illinois ....... & $4,291,066$ & $129,104,668$ & Michigan & $1,514,808$ & $36,956,425$ \\
\hline Minnesota & $3,429,079$ & $89,108,151$ & Ohio.... & $1,452,052$ & $46,818,330$ \\
\hline Wisconsin & $2,251,919$ & $68,296,223$ & Kansas & $1,415,928$ & $36,257,356$ \\
\hline North Dakota & $2,073,162$ & $30,294,074$ & North-Centril & & \\
\hline South Dakota. & $1,839,089$ & $51,091,904$ & States.............. & $29,206,759$ & $827,815,8 \mathrm{C} 4$ \\
\hline Indiana ............. & $1,718,748$ & $52,529,723$ & United States.... & $37,991,002$ & $1,055,182,798$ \\
\hline
\end{tabular}

In this bulletin there are discussed four new varieties of oats which have achieved a marked success in the Corn Belt and which in Iowa and adjacent States where they are adapted have added materially to production. These varieties were developed by the Iowa Agricultural Experiment Station in cooperation with the Bureau of Plant Industry of the United States Department of Agriculture. The four varieties, in the order of their distribution, are Albion (Iowa No. 103), Richland (Iowa No. 105), Iowar, and Iogren (Cereal Investigations Nos. 729, 787, 847, and 2024, respectively).

\section{HISTORY AND METHODS OF OAT EXPERIMENTS}

The experiments to develop improved varieties of oats for Iowa and the Corn Belt in general were begun in 1906. At harvest of that year 450 individual plant selections were made by the senior writer from the fifty-odd varieties and strains then being grown in the experimental plats of the Iowa station. With this as a beginning, more than 20,000 pure lines have since been isolated and studied, and $1, \tilde{5} 44$ of these have been of sufficient merit to warrant continuation in the nursery for at least three years. From the nursery, 150 of the best strains have been increased and advanced to the plat experiments, and of these superior strains four have been found so outstanding that they have been increased, named, and distributed to farmers. A harvested oat nursery at the Iowa Agricultural Experiment Station is shown in Figure 1.

T e methods of isolating pure lines and studying them in the nursery have been described in a previous publication. ${ }^{1}$ The plat experiments in which the merit of the 150 best strains was finally determined have been conducted under conditions conforming to good farm practice. Judgment as to the value of these strains has been based on average yields when grown in comparison with the best adapted commercial varieties for a series of years. Harvesting oat varieties grown in plats at the Iowa Agricultural Experiment Station is shown in Figure 2.

In order to determine the wider adaptation and performance of the improved varieties developed at the Iowa station, it was necessary that they be grown at various other points throughout the State. To make this possible there was organized the Iowa Agricultural Experiment Association, mads up of farmers who agreed to

1 Warburton, C. W., Burnett. L. C., and Love, H. H. Tests of selections from hybrids and commercial varieties of oats. U.'S. Dept. Agr. Bul, 99, 25 pp., illus. 1914. 
test improved varieties in comparison with standard commercial varieties under conditions as nearly identical as possible and to report their results to the association. The secretary of the association is a member of the staff of the Iowa Agricultural Experiment Station. Reports covering 971 comparative trials of this kind so far have been accumulated. In addition to supplying needed information, the grain threshed from these farm plats usually has been sown again on the same farms, these farms serving as seedgrowing centers from which the improved varieties have been widely distributed.

\section{ALBION (IOWA NO. 103)}

Experiments conducted prior to 1906 demonstrated that Kherson was one of the most dependable varieties of oats grown in the Corn

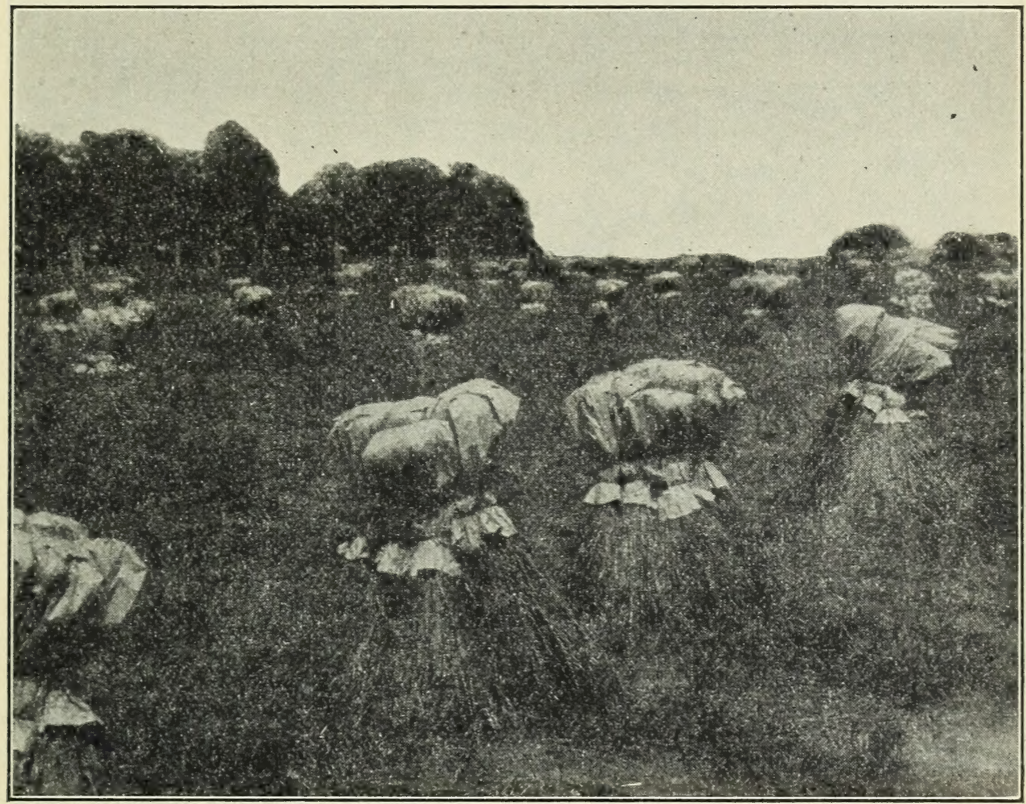

Fig. 1.-Harvested oat nursery at the Iowa Agricultural Experiment Station

Belt. The importance of the variety in this area is shown by the distribution map (fig. 3). On account of its yellow color it was discriminated against in the markets, and other varieties inferior to Kherson were grown, primarily because of their better color. There was a demand for a white oat with the vigor and yield of Kherson to replace these inferior varieties. Albion, a white strain of Kherson, was the first pure-line oat variety developed in the cooperative cereal experiments at the Iowa Agricultural Experiment Station. The history and description of this variety follow.

\section{HISTORY AND DESCRIPTION}

History.-Albion originated from a single white-kerneled plant selected from Kherson in 1906 by the senior writer. This selection 
was designated as Iowa No. 103. From 1906 to 1909 it was grown in the nursery, and in 1909, because of its nursery record, the first increase plat was grown. In 1910 it was placed in the plat varietal experiments. The variety was first distributed to Iowa farmers in 1913, distribution being continued by the Iowa Agricultural Experiment Station until 1917. From this wide distribution in Iowa the Albion spread to adjoining States and is to-day the leading early variety in Iowa and Illinois, although it is being replaced to some extent by the higher yielding selection Iowar, which is discussed elsewhere in this bulletin.

In 1919 Iowa grew slightly more than 1,000,000 acres of the Albion variety. Over 300,000 acres were grown in Illinois. The States

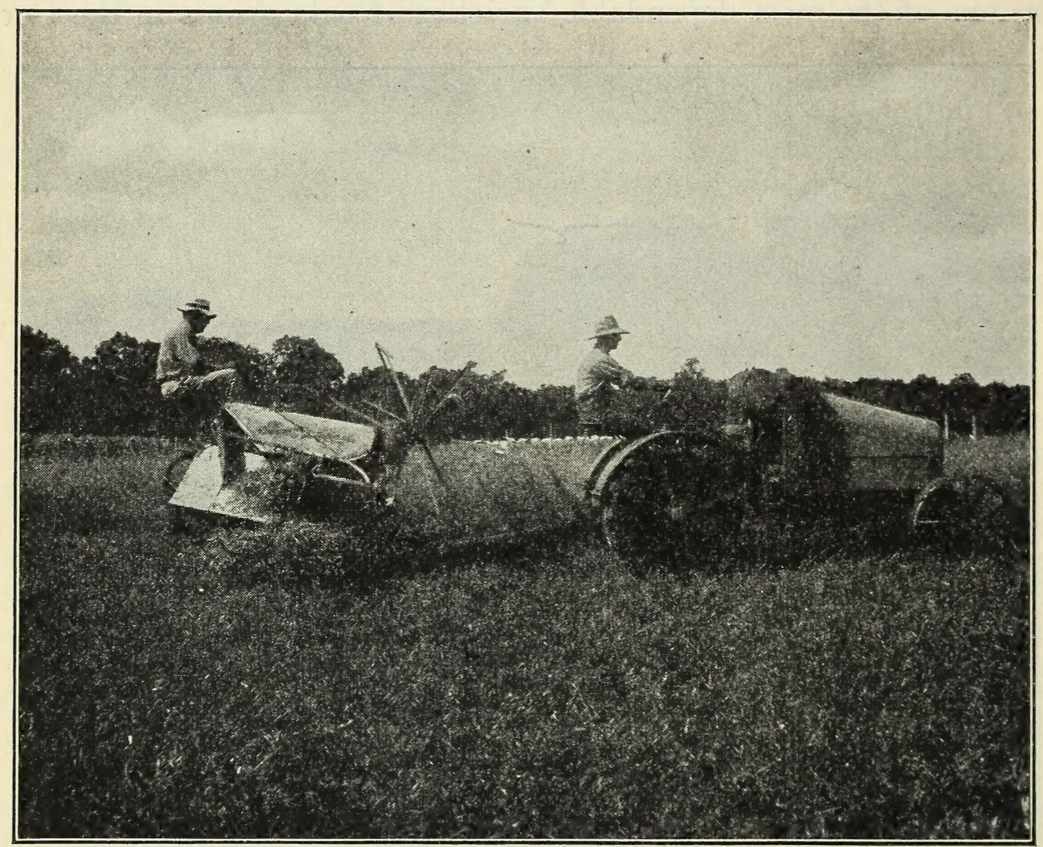

FIG. 2.-Harvesting Iowar oats on the Agronomy Farm of the Iowa Agricultural

of Minnesota, Missouri, Nebraska, South Dakota, and Wisconsin each grew from 11,000 to 19,000 acres in that year. At the then average farm price of 72 cents a bushel for oats and an average gain in yield of 3 bushels per acre p. 9), Iowa alone received a net gain of more than $\$ 2,000,000$ from this variety in that year. The distribution of Albion in 1919 is shown in Figure 4.

A more recent survey made by the Iowa Agricultural Experiment Station shows that in 1924 Albion was grown on 23.2 per cent (1,332,608 acres) of Iowa's total oat acreage of 5,744,000 acres, as compared with 8.7 per cent $(499,728$ acres) for Richland, 13.5 per cent $(775,440$ acres) for Iowar, and 0.8 per cent (45,952 acres) for Iogren. These figures indicate that the Albion has been well received by the farmers of Iowa. 
Description.-Early growth erect; plant early. Culms slender, weak, glabrous, sometimes slightly pubescent at the nodes, 60 to 90 centimeters tall. Sheaths deep green, glabrous; culm leaves narrow, margins glabrous. Peduncle slender, straight, usually well exserted. Panicle equilateral, usually erect, short, narrow to midbroad, ovate; rachis nodes five to six; branchcs short to midlong, usually ascending, scabrous. Spikelets few to rumerous, 2-flowered, occasionally 3 -flowered; kernel slender. Empty glumes 20 to 24 millimeters long, 5 to 7 millimeters wide, 8 to 9 veined, light green before maturity. Lower lemma 15 to 18 millimeters long, glabrous, white to slightly grayish white; basal hairs very few or wanting; awns few to abundant, straight (nontwisted) to twisted and frequently geniculate, 15 to 35 millimeters long. Upper lemma 10 to 13 millimeters long, awnless. Rachilla segment midlong, usually glabrous.

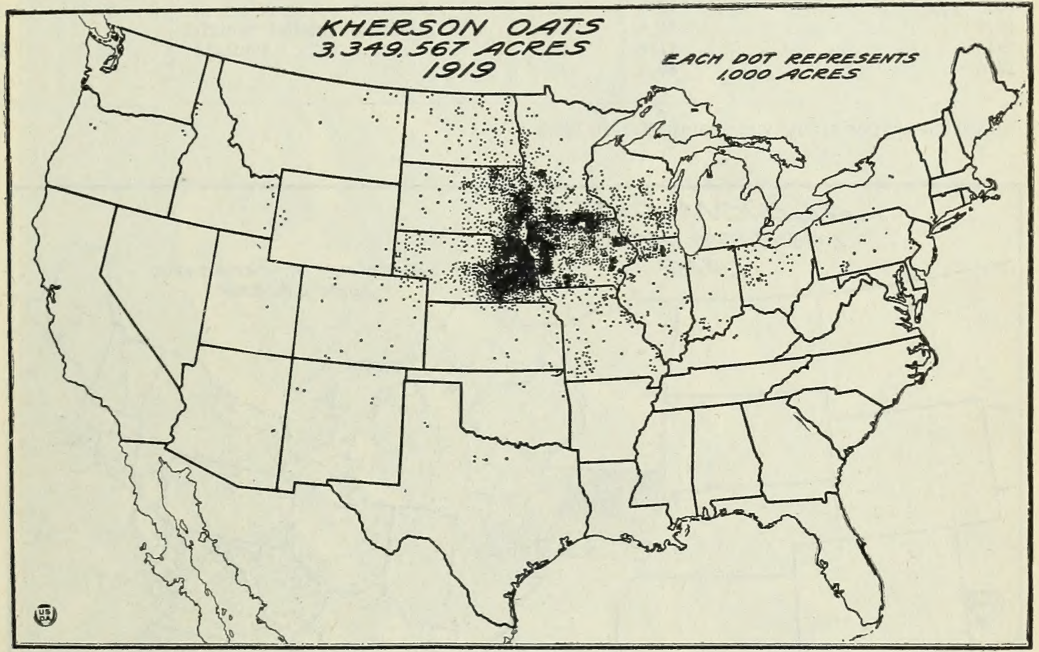

FIG. 3.-Outline map of the United States, showing distribution of the Kherson oat in 1919

The Albion differs primarily from Kherson, the parent variety, in having white lemmas and usually more awns. The straw and glumes are of a creamy yellow at maturity. The variety ripens one day earlier than Kherson and two days later than Early Champion, which was formerly a standard early variety on Iowa farms. A panicle and spikelets of Albion are shown in Figure 5.

\section{YIELDS OF ALBION}

EXPERIMENTS AT THE IOWA STATION

As the white-kerneled Albion was developed primarily as a substitute for the yellow Kherson, the two should be compared. Table 2 shows the average date of sowing, date of ripening, height of plant, percentage of lodging, bushel weight, and annual and average yields of grain of Albion and Kherson oats at the Iowa Agricultural Experiment Station for the 13 years from 1910 to 1919, inclusive, and 
in 1921, 1922, and 1923. The rate of seeding for each variety was 3 bushels per acre in all years.

TABLE 2.-Average dates of soving and of ripening, height of plant, percentage of lodging, bushel weight, and annual and average acre yields of the Albion and Kherson oat varieties at the Iowa Agricultural Experiment Station for the 13 years from 1910 to 1919, inclusive, and in 1921, 1922, and 1923 ${ }^{1}$

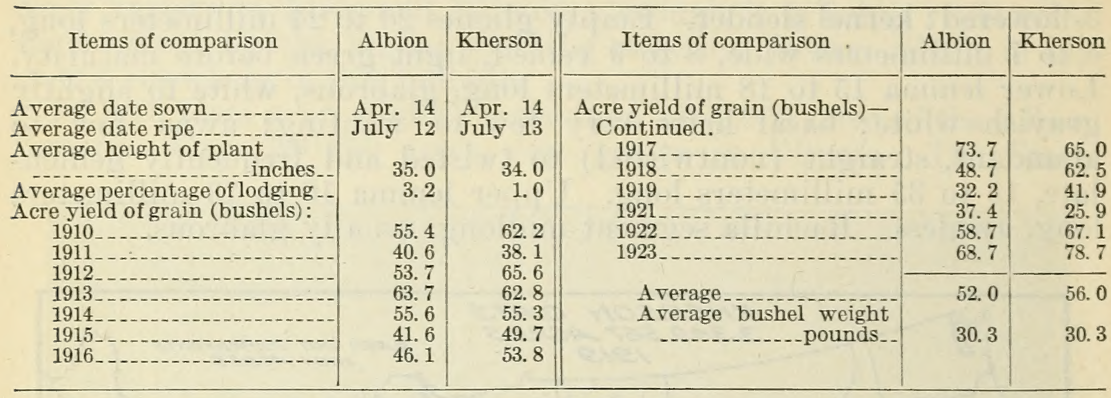

1 No varietal experiments were conducted in 1920.

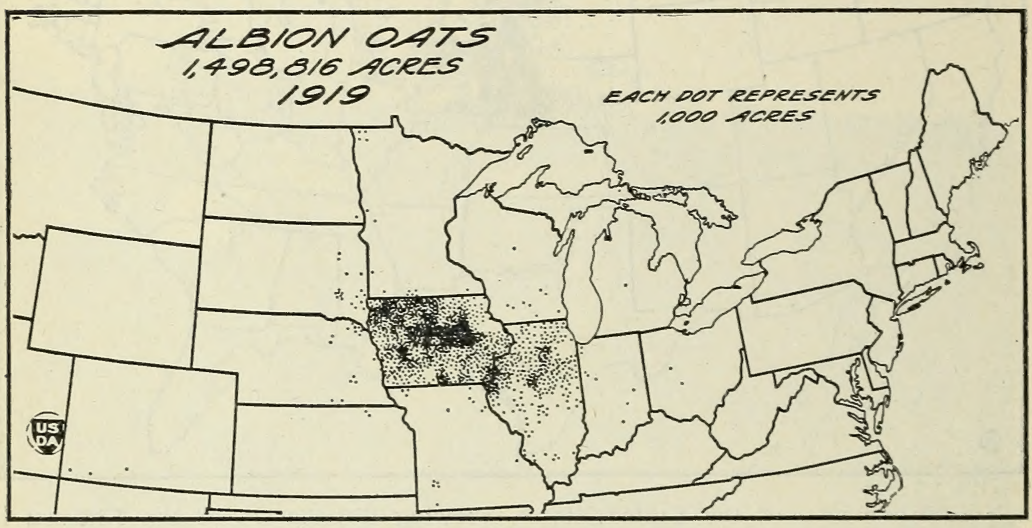

Fig. 4.- Outline map of a portion of the United States, showing distribution of the Albion oat in 1919

Table 2 shows that Albion is one day earlier than Kherson in maturity. In height of plant there is practically no difference. In yield, the original Kherson is superior, and in bushel weight they are practically equal.

A statistical study ${ }^{2}$ of the yields given in Table 2 indicate that there is no significant difference between the yielding power of the two varieties. The odds are only 19.6 to 1 that Kherson is a higher yielding variety than Albion. Odds as small as this are of little significance.

While the results obtained from the Albion oat in nursery experiments during 1907 and 1908 indicated that it was equal to the parent variety in yield and vigor, these indications were not substantiated by the results obtained from the early plat experiments, as shown

anonymous. The probable error of a mean, by Student. In Biometrica, vol. 6, pp. 1-25. 1908. 
in Table 2. Nevertheless, it was believed that the white hull of the kernel was of sufficient importance to warrant its increase and distribution to farmers to determine its value under farm conditions. The farm record of the variety fully justified this decision

\section{EXPERIMENTS ON IOWA FARMS}

Yields of Albion in comparison with Kherson were obtained on 66 Iowa farms during the five-year period from 1913 to 1917, inclusive,

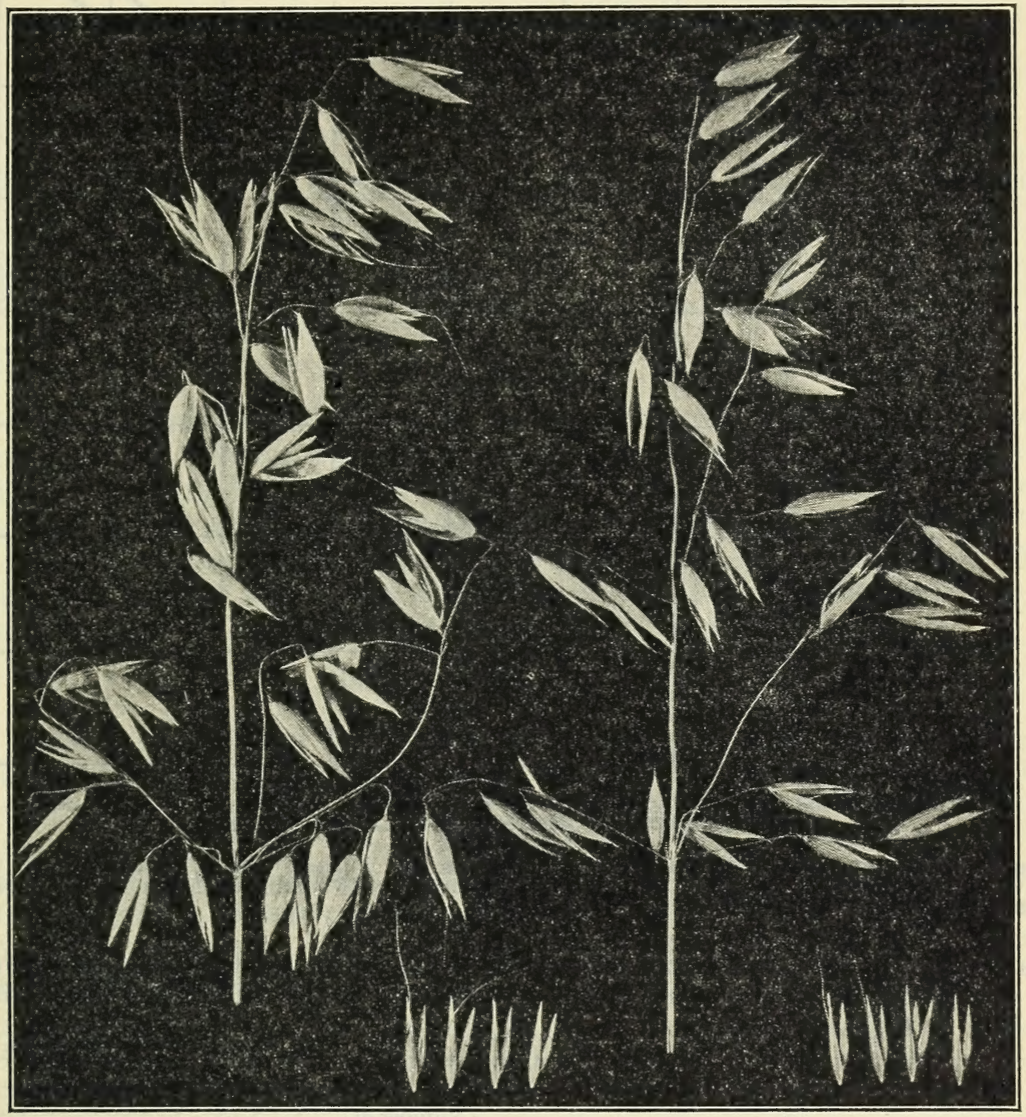

Fig. 5.-Panicles and spikelets of the Albion (left) and Richland (right) oat varieties

through the cooperation of the Iowa Agricultural Experiment Association and the Iowa Agricultural Experiment Station, previously mentioned. In Table 3 are given the summarized yields from these tests.

According to the data presented in Table 3, Albion outyielded the original Kherson variety on Iowa farms by an average of 3.02 bushels per acre. These yields, therefore, inclicate that Albion is more productive than Kherson on Iowa farms, even though it has been inferior to Kherson in the experiments at the Iowa Agricultural Experiment Station, as shown in Table 2. The relative yielding 
power of the two varieties as indicated by the mean yields from the 66 comparative tests is shown graphically in Figure 6. Space does not permit the presentation of the detailed data from these experiments.

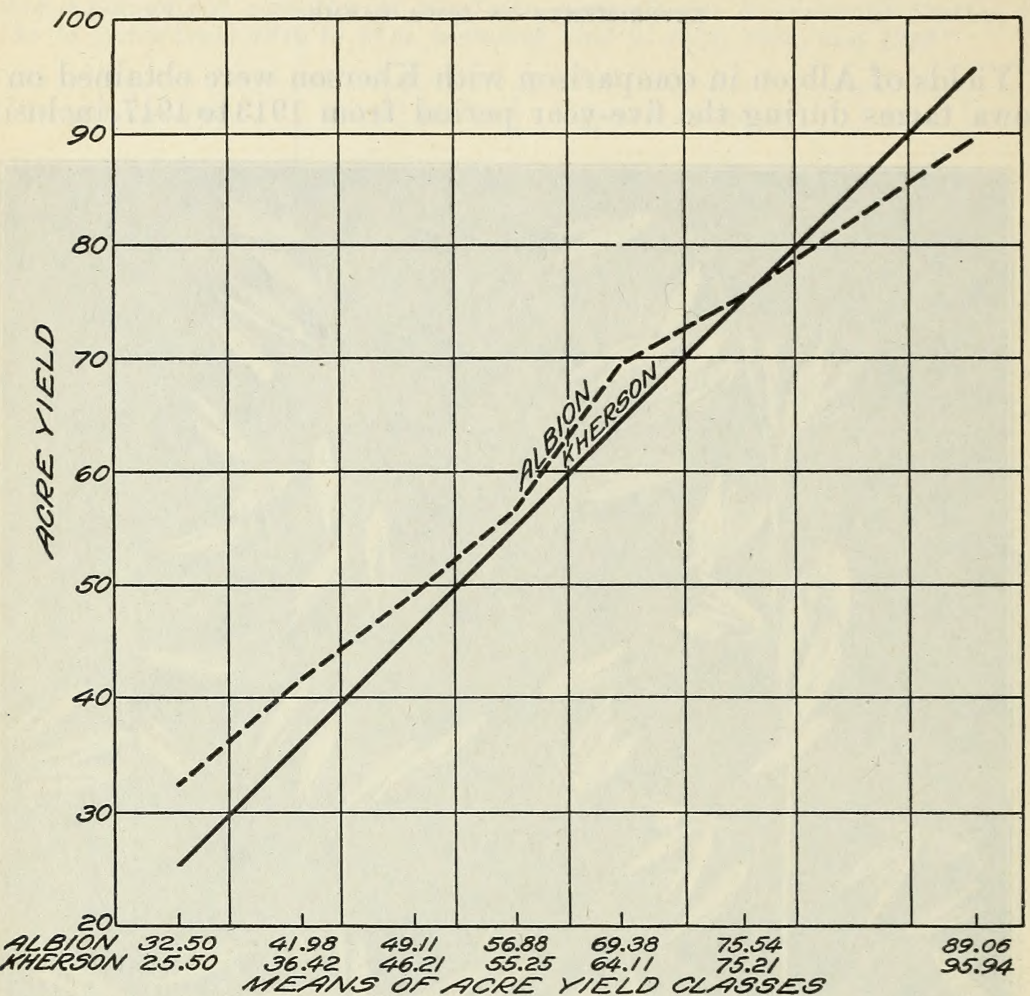

FIG. 6.-Diagram showing the mean acre yields (in bushels) of Albion as compared with those of Kherson as a standard oat variety in 66 trials on Iowa farms during the 5-year period from 1913 to 1917 , inclusive.

TABLE 3.-Annual average and weighted average yields of the Albion and Kherson oat varieties grown on 66 Iowa farms during the five-year period from 1913 to 1917 , inclusive

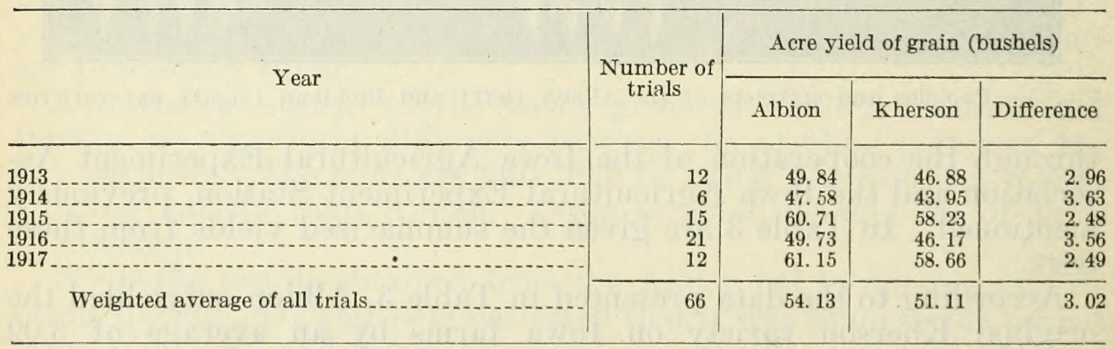

Albion also was compared in a similar way with several other varieties on Iowa farms, altogether 267 trials being conducted during the five years from 1913 to 1917, inclusive. The summarized 
results are presented in Table 4 . The home-grown varieties and the number of trials in which each was compared with the Albion were as follows: Swedish Select 37, Silvermine 20, Early Champion 26, Kherson 66, Green Russian 34, miscellaneous 27, and unknown varieties 57.

TABLE 4.-Average yields of Albion and other common varieties of oats groun on 267 Iowa farms during the five-year period from 1913 to 1917 , inclusive

\begin{tabular}{|c|c|c|c|c|}
\hline \multirow[b]{2}{*}{ Home-grown variety } & \multirow[b]{2}{*}{$\underset{\text { trials }}{\text { Number of }}$} & \multicolumn{3}{|c|}{ Acre yield of grain (bushels) } \\
\hline & & Albion & $\begin{array}{l}\text { Home- } \\
\text { grown } \\
\text { variety }\end{array}$ & Difference \\
\hline $\begin{array}{l}\text { Swedish Select } \\
\text { Silvermine } \\
\text { Early Champion } \\
\text { Kherson } \\
\text { Green Russian } \\
\text { Miscellaneous varieties } \\
\text { Unknown varieties. }\end{array}$ & $\begin{array}{l}37 \\
20 \\
26 \\
66 \\
34 \\
27 \\
57\end{array}$ & $\begin{array}{l}46.98 \\
51.07 \\
50.38 \\
54.13 \\
52.51 \\
48.91 \\
48.83\end{array}$ & $\begin{array}{l}\text { 39. } 74 \\
44.70 \\
46.00 \\
51.11 \\
49.57 \\
42.82 \\
45.56\end{array}$ & $\begin{array}{l}\text { 7. } 24 \\
\text { 6. } 37 \\
\text { 4. } 38 \\
\text { 3. } 02 \\
\text { 2. } 94 \\
\text { 6. } 09 \\
\text { 3. } 27\end{array}$ \\
\hline Weighted average of all trials_ & 267 & 50.68 & 46. 34 & 4. 34 \\
\hline
\end{tabular}

The data of Table 4 show an average annual gain of 4.34 bushels per acre for Albion over these home-grown varieties. Some of the difference probably was due to the better quality of the Albion seed, as this seed was always cleaned and prepared by the Iowa station. Allowing a reasonable reduction for this factor, it is safe to estimate that the variety has raised the average yields on the fields where it has been grown in Iowa by at least 3 bushels per acre.

\section{RATIO OF GRAIN TO STRAW}

Albion is an early variety and, as would be expected, has a comparatively high yield of grain in proportion to straw. For three years the soils section of the Iowa Agricultural Experiment Station used this variety on the fertility plats at the station farm. The average acre yield of grain on 59 plats in 1915,1916 , and 1917 was 60.9 bushels (1,948.8 pounds). The average yield of grain from 1 ton of bundles was 1,124 pounds, or 56 per cent grain and 44 per cent straw by weight.

TABLE 5.-Acre yield and bushel weight of the Albion oat sown at varying rates at the Iowa Agricultural Experiment Station in 1912

\begin{tabular}{|c|c|c|c|c|c|c|c|}
\hline \multirow[b]{2}{*}{ Specification } & \multicolumn{6}{|c|}{ Rate of seeding per acre } & \multirow[b]{2}{*}{ Average } \\
\hline & $\stackrel{2}{\text { bushels }}$ & $\begin{array}{c}21 / 2 \\
\text { bushels }\end{array}$ & $\begin{array}{c}3 \\
\text { bushels }\end{array}$ & $\begin{array}{c}31 / 2 \\
\text { bushels }\end{array}$ & $\begin{array}{c}4 \\
\text { bushels }\end{array}$ & $\begin{array}{c}41 / 2 \\
\text { bushels }\end{array}$ & \\
\hline $\begin{array}{l}\text { Acre yield } \\
\text { Bushel weight_......... bushels_. }\end{array}$ & $\begin{array}{l}81.25 \\
30.75\end{array}$ & $\begin{array}{l}82.40 \\
31.50\end{array}$ & $\begin{array}{l}87.90 \\
32.00\end{array}$ & $\begin{array}{l}80.90 \\
32.00\end{array}$ & $\begin{array}{l}\text { 78. } 10 \\
32.00\end{array}$ & $\begin{array}{l}76.60 \\
33.00\end{array}$ & $\begin{array}{l}81.19 \\
31.88\end{array}$ \\
\hline
\end{tabular}

\section{RATE-OF-SEEDING EXPERIMENTS}

The Albion oat was grown in a rate-of-seeding experiment in 1912 only. The data obtained in this experiment are shown in Table 5. $43524^{\circ}-25-2$ 
While these data are too limited for conclusions, their trend is similar to that of more extensive data obtained with other similar rarieties, and in seeding this rariety the Iowa station has used and recommended the 3-bushel rate.

\section{RICHLAND (IOWA NO. 105)}

Richland, a yellow strain of Kherson, was the second pure line of that variety developed in the cooperative cereal experiments at the Iowa Agricuitural Experiment Station. The history and description of this strain follow.

\section{HISTORY AND DESCRIPTION}

History.-Richland is a companion strain of Albion and therefore has practically the same history. Like Albion, the original plant selection from Kherson was made by the senior writer in 1906. This selection was given the designation Iowa No. 105. It was grown in nursery experiments during the years 1907, 1908, and 1909 and was then advanced to the plat experiments. Owing to the excellent yields shown in these trials it was increased and first distributed to the farmers of Iowa in 1914. During the four succeeding rears up to and including 1918, this increase and distribution of Richland were continued.

In productireness, Richland has been one of the rery best strains of Kherson so far isolated. Its yielding ability together with its earliness and short, rather stiff straw makes this strain particularly adapted for growing on soils of high fertility where other varieties usually lodge. The name Richland is a recognition of this fact.

Description.-Early growth erect; plant rery early. Culms slender, stiff, glabrous or occasionally slightly hairy at the nodes,

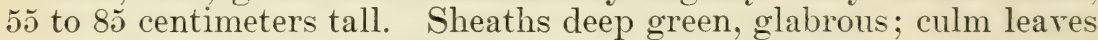
narrow, margins glabrous. Peduncle slender, straight, usually well exserted. Panicle equilateral, usually erect; short, narrow to midbroad, ovate; rachis nodes five to six; branches short to midlong. usually ascending, scabrous. Spikelets few to numerous, 2 -flowered; kernels slender. Empty glumes 20 to 24 millimeters long, $\check{5}$ to 7 millimeters wide, 8 to 9 veined, light green before maturity. Lower lemma 15 to 18 millimeters long, glabrous, bright yellow; basal hairs few to absent; amns usually few, straight (nontwisted) to twisted and geniculate, 10 to 30 millimeters long. Rachilla segment midlong, usually glabrous.

The Richland (Iowa No. 105) differs prumarily from the original Kherson in haring a slightly shorter straw. At time of ripening the empty glumes are a creamy white and the lemmas a distinct bright yellow. The variety ripens one day earlier than Kherson and two days later than Early Champion. It is resistant to stem rust of oats. A panicle and spikelets of Richland are shown in Figure 5 .

In a varietal survey it was estimated that nearly 411,000 acres of this improved strain of Kherson were grown in 1919. More than 90 per cent of this acreage was reported from Iowa, as is shown in Figure 7 . Despite favorable vields, however, the extension of Richland has been handicapped by its yellow color. as is proved by the fact that in 1924 the area deroted to it in Iowa had increased to only slightly less than a half million acres. 


\section{YIELDS OF RICHLAND}

EXPERIMENTS AT THE IOWA STATION

Like the Albion variety, the yielding porrer of Richland has been determined in extensive varietal experiments conducted at the Iowa Agricultural Experiment Station. The annual and average yields of Richland and Kherson, the parent variety, for the 13 years from 1910 to 1919 , inclusive, and in 1921, 1922, and 1923, together with the arerage date of sowing, date of ripening, height of plant, percentage of lodging, and bushel weight, are shown in Table 6 .

According to the data presented in Table 6, Richland for the 13 years has outyielded the Kherson by 3.8 bushels per acre. Thile yields of Richland at the Iowa station as well as elsewhere have been very favorable, this variety has not shown the wide range of adaptability that has characterized the Albion. Further, a statis-

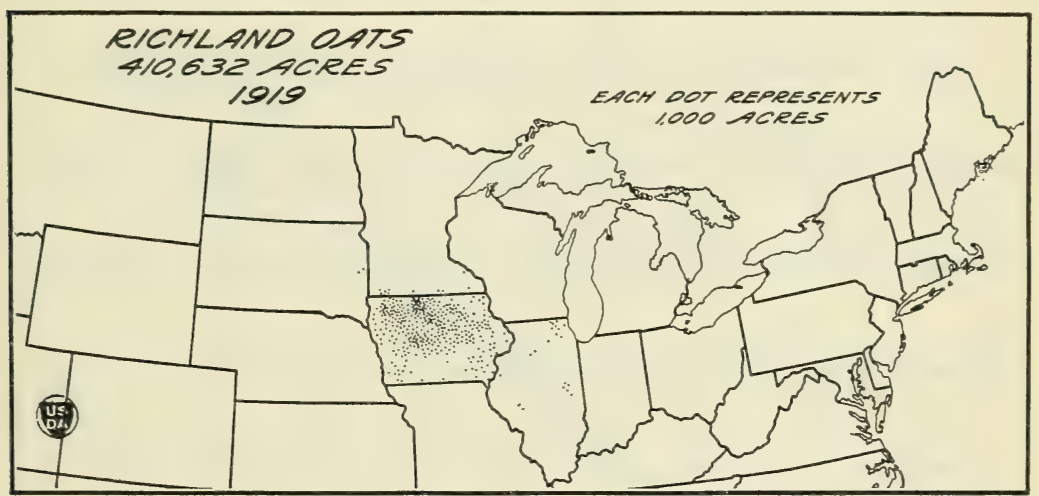

Fig. 7.-Outline map of a portion of the United States, showing distribution of the Richland oat in 1919

tical study ${ }^{3}$ of the yields of Richland and the parent variety Kherson, given in Table 6 , shows odds of 19.5 to 1 that Richland is superior in yielding power.

TABLE 6.-Average dates of sowing and of ripening, height of plants, percentage of lodging, bushel ueight, and annual and average acre yields of the Richland and Kherson oat varieties at the Ioua Agricultural Experiment Station for the 13 years from 1910 to 1919 , inclusive, and in 1921, 1922, and 1923 ${ }^{1}$

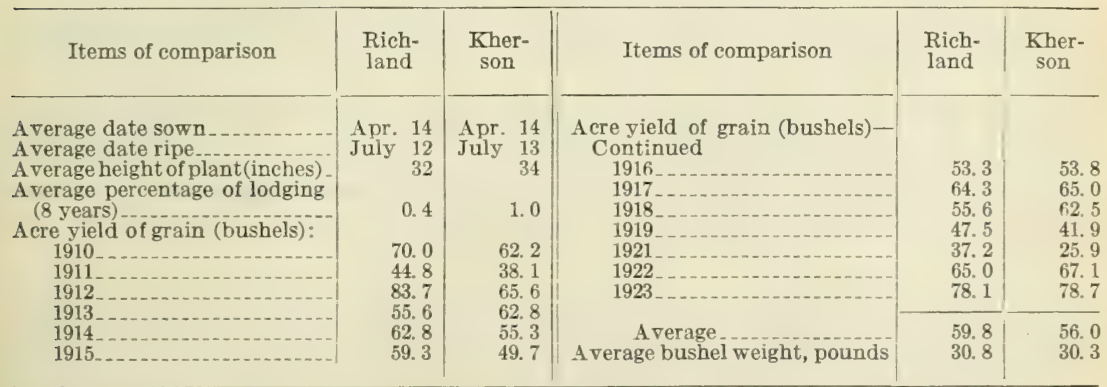

1 No varietal experiments were conducted in 1920.

s See footnote 2 , page 6 . 
The short straw has been an advantage only on the richer soils, and in some instances where the rariety has been sown on less fertile land it has been too short for convenient harresting. Richland is recommended primarily as a special-purpose variety for growing on rich soils where other varieties usually lodge and also in cases where the use of a short-strawed early oat as a nurse crop is an important consideration.

\section{EXPERIMENTS ON IOWA FARMS}

Richland also was included in the farm experiments of the Iowa Agricultural Experiment Association. One of the most interesting

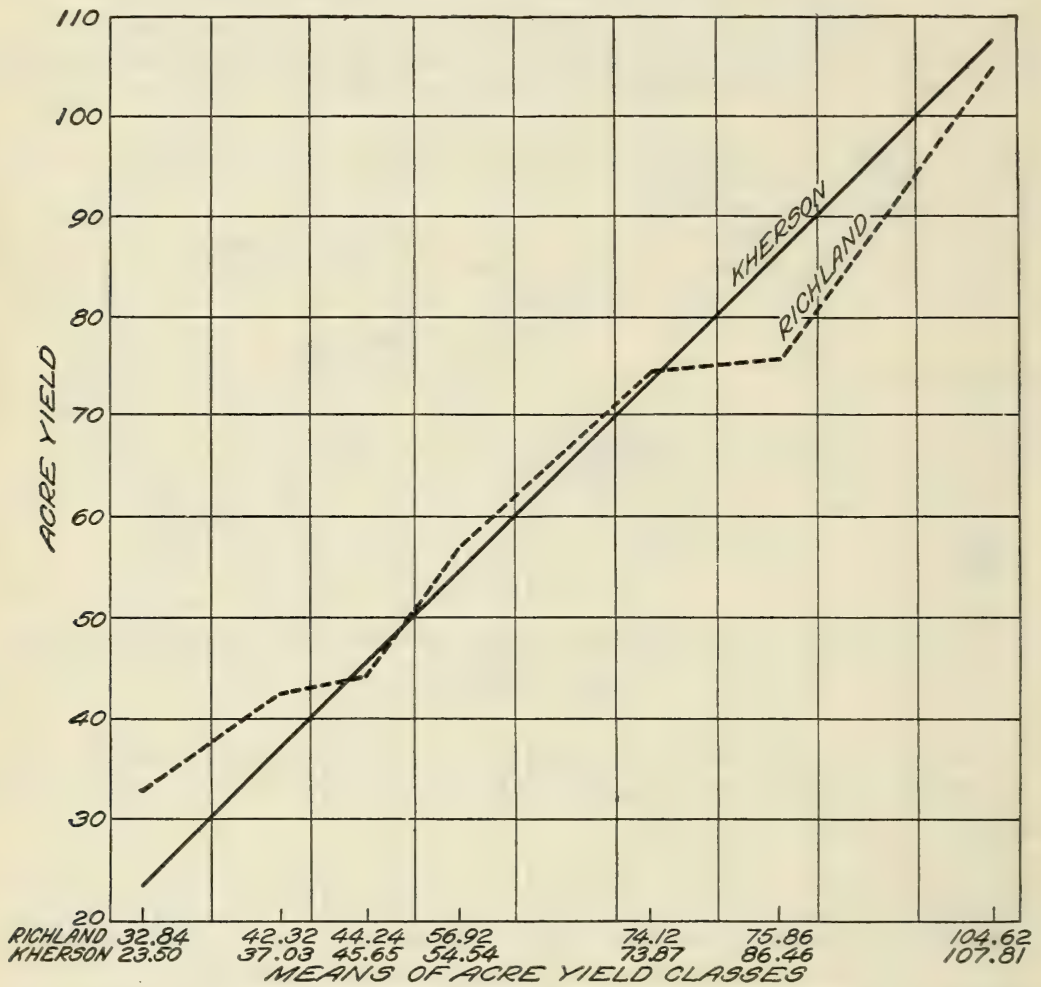

FIG. 8.-Diagram showing the mean acre rields (in bushels) of Richland as compared with those of Kherson as a standard oat variety in 46 trials on Iowa farms during the five-year period from 1914 to 1918 , inclusive

phases of these experiments was the comparison of Richland with the parent variety Kherson. In Table $\tau$ are given the annual arerage and weighted arerage vields of Richland and Kherson obtained on 46 Iowa farms during the fire-year period from 1914 to 1918 , inclusive.

The data in Table 7 show that on Iowa farms Richland outyielded its parent variety Kher'son by only 1.3 bushels per acre during the five years from 1914 to 1918 , inclusive. The almost identical vielding power of these varieties as indicated by the mean yields from the 46 
farm tests is shown graphically in Figure 8. Space does not permit the presentation of these data in detail.

TABLE 7.-Annual average and weighted average yields of the Richland and Kherson out varieties grown on 46 Iou farms during the five-year period from 1914 to 1918, inclusive

\begin{tabular}{|c|c|c|c|c|}
\hline \multirow{2}{*}{ Year } & \multirow{2}{*}{$\underset{\text { trials }}{\text { Number of }}$} & \multicolumn{3}{|c|}{ Acre yield of grain (bushels) } \\
\hline & & Richland & Kherson & Difference \\
\hline 1914 & $\begin{array}{r}6 \\
9 \\
13 \\
16 \\
2\end{array}$ & $\begin{array}{l}51.81 \\
57.87 \\
48.51 \\
64.36 \\
52.22\end{array}$ & $\begin{array}{l}46.54 \\
51.57 \\
47.91 \\
65.01 \\
65.23\end{array}$ & $\begin{array}{r}5.27 \\
6.30 \\
.60 \\
.65 \\
13.01\end{array}$ \\
\hline Weighted average of all trials... & 46 & 56.45 & 55.15 & 1. 30 \\
\hline
\end{tabular}

The Richland also was compared with a number of other homegrown varieties, 195 such comparisons being made. The varieties and number of trials in which each was compared with Richland were as follows: Early Champion 18, Silvermine 14, Swedish Select 20, Green Russian 29, Kherson 46, miscellaneous 36, and unknown 32. The average annual and weighted arerage yields in bushels per acre of the Richland and of the home-grown varieties, with their differences, are shown in Table 8.

TABLE 8.-Average yields of Richland and other common varieties of oats grown on 195 Iowa farms during the five-year period from 1914 to 1918, inclusive

\begin{tabular}{|c|c|c|c|c|}
\hline \multirow[b]{2}{*}{ Home-grown varieties } & \multirow[b]{2}{*}{$\begin{array}{c}\text { Number of } \\
\text { trials }\end{array}$} & \multicolumn{3}{|c|}{ Acre yield of grain (bushels) } \\
\hline & & Richland & $\begin{array}{l}\text { Home- } \\
\text { grown } \\
\text { variety }\end{array}$ & Difference \\
\hline $\begin{array}{l}\text { Early Champion } \\
\text { Silvermine } \\
\text { Swedish Select } \\
\text { Green Russian } \\
\text { Kherson } \\
\text { Miscellaneous varieties. } \\
\text { Unknown varieties. }\end{array}$ & $\begin{array}{l}18 \\
14 \\
20 \\
29 \\
46 \\
36 \\
32\end{array}$ & $\begin{array}{l}57.19 \\
59.18 \\
41.77 \\
48.98 \\
56.45 \\
52.67 \\
54.91\end{array}$ & $\begin{array}{l}51.56 \\
54.84 \\
39.22 \\
46.90 \\
55.15 \\
50.49 \\
52.32\end{array}$ & $\begin{array}{l}\text { 5. } 63 \\
\text { 4. } 34 \\
2.55 \\
\text { 2. } 08 \\
\text { 1. } 30 \\
\text { 2. } 18 \\
\text { 2. } 59\end{array}$ \\
\hline Weighted average of all trials_.. & 195 & 53.15 & 50.61 & 2. 54 \\
\hline
\end{tabular}

From the data shown in Table 8 , it will be seen that on the average Iowa farm Richland has exceeded the home-grown varieties in average yield from 1.3 to 5.6 bushels per acre.

COMPARATIVE YIELDS OF RICHLAND AND ALBION

EXPERIMEXTS AT THE IOWA STATION

A comparison of the annual and average yields of Richland and Albion at the Iowa Agricultural Experiment Station is presented in Table 9. 
TABLE 9.-Annual and average acre yields of the Richland and Albion oat varieties at the Iowa Agricultural Experiment Station during the 13 years from 1910 to 1919 , inclusive, and in 1921, 1922, and 1923 ${ }^{1}$

\begin{tabular}{|c|c|c|c|c|c|c|c|c|c|}
\hline \multirow{3}{*}{ Year } & \multicolumn{4}{|c|}{ Acre yields of grain (bushels) } & \multirow{3}{*}{ Year } & \multicolumn{4}{|c|}{ Acre yields of grain (bushels) } \\
\hline & \multirow[t]{2}{*}{ Richland } & \multirow[t]{2}{*}{ Albion } & \multicolumn{2}{|c|}{$\begin{array}{l}\text { Difference in } \\
\text { favor of - }\end{array}$} & & \multirow[t]{2}{*}{ Richland } & \multirow[t]{2}{*}{ Albion } & \multicolumn{2}{|c|}{$\begin{array}{l}\text { Difference in } \\
\text { favor of - }\end{array}$} \\
\hline & & & Richland & Albion & & & & Richland & Albion \\
\hline \multirow{5}{*}{$\begin{array}{l}1910 \\
1911 \\
1912 \\
1913 \\
1914 \\
1915 \\
1916 \\
1917\end{array}$} & \multirow{5}{*}{$\begin{array}{l}70.0 \\
44.8 \\
83.7 \\
55.6 \\
62.8 \\
59.3 \\
53.3 \\
64.3\end{array}$} & \multirow{5}{*}{$\begin{array}{l}55.4 \\
40.6 \\
53.7 \\
63.7 \\
55.6 \\
41.6 \\
46.1 \\
73.7\end{array}$} & \multirow{2}{*}{$\begin{array}{r}14.6 \\
4.2 \\
30.0\end{array}$} & \multirow{5}{*}{8.1} & \multirow{5}{*}{$\begin{array}{r}1918 \\
1919 \\
1921 \\
1922 \\
\text { Average }\end{array}$} & \multirow{4}{*}{$\begin{array}{l}55.6 \\
47.5 \\
37.2 \\
65.0 \\
78.0\end{array}$} & \multirow{4}{*}{$\begin{array}{l}48.7 \\
32.2 \\
37.4 \\
58.7 \\
68.7\end{array}$} & \multirow[t]{2}{*}{$\begin{array}{r}6.9 \\
15.3\end{array}$} & \\
\hline & & & & & & & & & \\
\hline & & & & & & & & 6.3 & \\
\hline & & & $\begin{array}{r}7.2 \\
17.7\end{array}$ & & & & & 9.3 & \\
\hline & & & 7.2 & & & 59.8 & 52.0 & 7.8 & \\
\hline
\end{tabular}

1 No varietal experiments were conducted in 1920.

For the 13 years from 1910 to 1919, inclusive, and in 1921, 1922 , and 1923, according to the data presented in Table 9, the Richland outyielded the Albion by nearly 8 bushels to the acre. This decided advantage in favor of Richland is not paralleled by the results on Iowa farms. However, the farm tests cover only two years, and the data, therefore, can not be considered as conclusive.

EXPERIMENTS ON IOWA FARMS

During the years 1916 and 1917 the Iowa Agricultural Experiment Station distributed seed of both Albion and Richland to 54 farmers for trial. A summary of the yields obtained from these experiments is shown in Table 10.

TABLE 10.-Average acre yields of Richland and Albion oat varieties from. 5' separate comparative trials on Iowa farms in 1916 and 1917

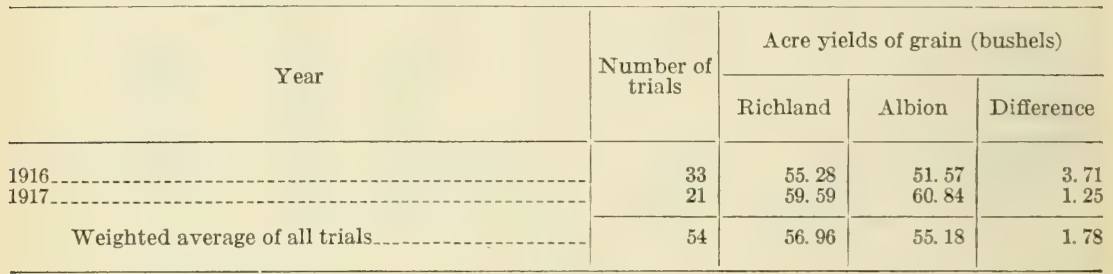

In the 54 trials in which Richland and Albion oats were grown in adjacent acre plats, the Richland has exceeded the Albion by an average yield of only 1.78 bushels. These average results indicate that Richland when grown on ordinary prairie soil probably will not produce so well as on the more fertile soils of the Iowa Agricultural Experiment Station Farm. Apparently, on the average soils of the State these two rarieties may be expected to give almost identical yields.

\section{RATE-OF-SEEDING EXPERIMENTS}

Rate-of-seeding experiments with Richland vere conducted during the 6-year period from 1912 to 1917 , inclusive. In Table 11 are 
given the annual and average acre yields of Richland oats sown at rates varying from 2 to $4 \frac{1}{2}$ bushels per acre.

TABLE 11.-Annual and average acre yiclds (in bushels) of Richland oats sown in rate-of-seeding experiments at the Ioua Agriculturul Experiment Station during the six-year period from 1912 to 1917 , inclusive

\begin{tabular}{|c|c|c|c|c|c|c|}
\hline \multirow[b]{2}{*}{ Year } & \multicolumn{6}{|c|}{ Rate of seeding per acre } \\
\hline & $\stackrel{2}{\text { bushels }}$ & $\begin{array}{c}21 / 2 \\
\text { bushels }\end{array}$ & $\stackrel{3}{\text { bushels }}$ & $\begin{array}{c}31 / 2 \\
\text { bushels. }\end{array}$ & $\stackrel{4}{\text { bushels }}$ & $\begin{array}{c}41 / 2 \\
\text { bushels }\end{array}$ \\
\hline $\begin{array}{l}1912 \\
1913 \\
1914 \\
1915 \\
1916 \\
1917\end{array}$ & $\begin{array}{l}83.6 \\
70.6 \\
51.4 \\
82.3 \\
55.6 \\
73.7\end{array}$ & $\begin{array}{l}80.5 \\
68.7 \\
51.4 \\
83.4 \\
55.0 \\
78.1\end{array}$ & $\begin{array}{l}79.7 \\
72.5 \\
59.0 \\
82.3 \\
57.0 \\
87.5\end{array}$ & $\begin{array}{l}78.1 \\
76.9 \\
55.2 \\
83.6 \\
58.8 \\
87.5\end{array}$ & $\begin{array}{l}75.8 \\
72.8 \\
55.6 \\
81.6 \\
58.2 \\
81.2\end{array}$ & $\begin{array}{l}72.7 \\
67.5 \\
55.0 \\
83.6 \\
53.5 \\
68.7\end{array}$ \\
\hline Average & 69.5 & 69.5 & 73.0 & 73.4 & 70.9 & 66.8 \\
\hline
\end{tabular}

The data in Table 11 show that the optimum net rate of seeding for the 6-year period was 3 bushels per acre. Above this rate an increase in rate of seeding was not profitable, and above the $31 / 2^{-}$ bushel rate there was an actual decrease in yield, the decrease being greater with the increase in rate of seeding.

\section{IOWAR}

Iowar, a white strain of Kherson, is the third pure-line oat variety developed in the cooperative oat experiments at the Iowa Agricultural Experiment Station that has been distributed to farmers.

\section{HISTORY AND DESCRIPTION}

History.-Iowar was isolated from Kherson in 1910 by the senior writer. It was carried under the tentative designation of Iowa No. 779 and was named Iowar when first distributed to farmers. The nursery results in 1912,1913 , and 1914 were so favorable that it was increased and placed in the plat experiments in 1916. It was immediately apparent that this new strain excelled Albion in at least two very important characters, namely, in yielding ability and in height of plant. As there was a rather insistent demand for a variety of this type, it was decided to increase Iowar at once and to test it immediately on Iowa farms. The variety was first distributed to farmers of Iowa in 1919. Its increase and distribution have continued each year.

Description.--Early growth erect; plant early. Culms slender to midsized, weak, glabrous or slightly hairy at the nodes, 70 to 110 centimeters tall. Sheaths deep green, usually glabrous; culm leaves narrow to midwide, margins usually glabrous. Peduncle slender, straight, usually well exserted. Panicle equilateral, usually erect, midbroad, ovate; rachis nodes five to six; branches short to midlong, usually ascending, scabrous. Spikelets few to numerous, usually twoflowered; kernels slender. Empty glume 20 to 24 millimeters long, 5 to 7 millimeters wide, 8 to 9 veined, light green before maturity. Lower lemma 15 to 18 millimeters long, white; basal hairs few or 
absent; awns usually rather abundant, straight (nontwisted) to twisted and geniculate, 15 to 35 millimeters long. Upper lemma 10 to 14 millimeters long, a rnless. Rachilla segment midlong, usually glabrous.

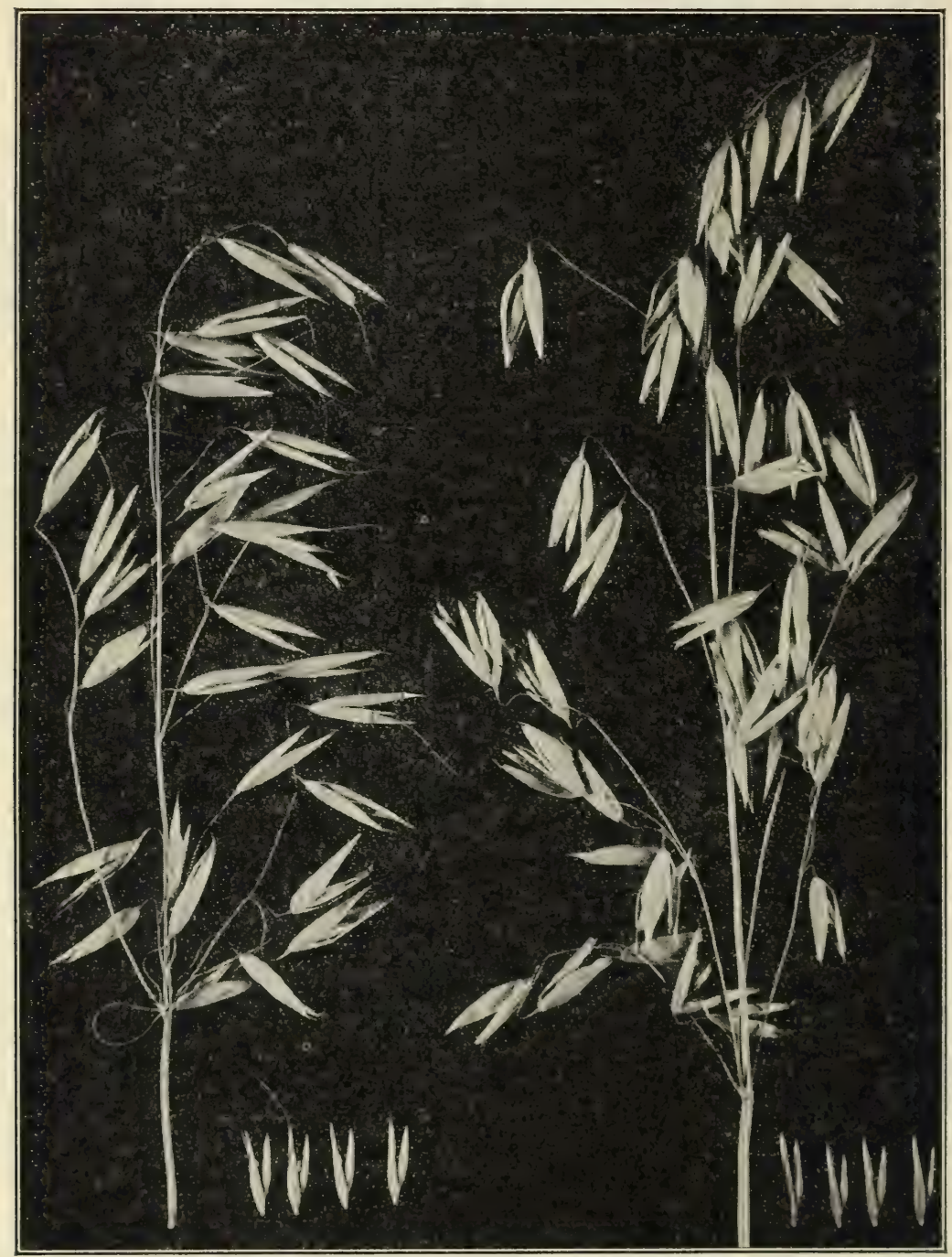

FIg. 9.-Panicles and spikelets of the Iowar (left) and Iogren (right) oat varieties

Iowar differs from the Albion mainly in its slightly coarser and taller straw. Under average field conditions it grows about 2 inches taller than Albion. It also produces more awned spikelets, and the awns are distinctly dark at the base. At maturity the glumes are creamy white in color. It ripens about two days later than Kherson and three days later than Albion and Richland. A panicle and spikelets of Iowar are shown in Figure 9. 


\section{YIELDS OF IOWAR}

EXPERIMENTS AT THE IOWA STATION

In two of the seven seasons that Iowar has been grown at the Iowa station the variety has been subject to mishap. In 1917 Iowar was badly damaged by flood, and in 1919 a large part of the grain was lost because of a storm which occurred after the variety was ripe and before it could be harrested. Data for six years are given, but the data of only five seasons are comparable as a basis for averages for this variety.

The average date of seeding, date of ripening, height of plant, percentage of lodging, bushel weight, and the annual and average yields of the Iowar, Kherson, Albion, and Richland varieties at the Iowa Agricultural Experiment Station for the seven years from 1916 to 1919 , inclusive, and in 1921, 1922, and 1923 are given in Table 12.

TABLE 12.-Average dates of souing and of ripening, height of plant, percentage of lodging, bushel weight, and the annual and average acre yields of the Iouar, Richland, Albion, and Kherson oat varicties at the Iowa Agricultural Experiment Station for the seven years from 1916 to 1919 , inclusive, and in 1921,1922 , and $1923^{1}$

\begin{tabular}{|c|c|c|c|c|}
\hline Items of comparison & Iowar & Kherson & Albion & $\begin{array}{l}\text { Rich- } \\
\text { land }\end{array}$ \\
\hline $\begin{array}{l}\text { Average date sown } \\
\text { Average date ripe } \\
\text { Average height of plant } \\
\text { A verage percentage of lodging } \\
\text { A verage yield of grain (bushels): } \\
1916\end{array}$ & $\begin{array}{r}\text { Apr. } 14 \\
\text { July } \\
36 \\
24 \\
\\
56.7 \\
57.5 \\
62.5 \\
(2) \\
41.2 \\
60.6 \\
87.8\end{array}$ & $\begin{array}{r}\text { Apr. } 14 \\
\text { July } \\
13 \\
34 \\
6 \\
\\
53.8 \\
65.0 \\
62.5 \\
41.9 \\
25.9 \\
67.8 \\
78.7\end{array}$ & $\begin{array}{r}\text { Apr. } 13 \\
\text { July } 12 \\
34 \\
11 \\
\\
46.1 \\
73.7 \\
48.7 \\
32.2 \\
37.4 \\
58.7 \\
68.7\end{array}$ & $\begin{array}{r}\text { Apr. } 14 \\
\text { July } 12 \\
31 \\
4 \\
\\
53.6 \\
64.3 \\
55.6 \\
47.5 \\
37.2 \\
65.0 \\
78.1\end{array}$ \\
\hline 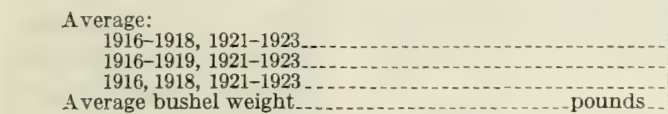 & $\begin{array}{r}61.1 \\
61.8 \\
31.1\end{array}$ & $\begin{array}{l}59.0 \\
56.5 \\
57.7 \\
30.9\end{array}$ & $\begin{array}{l}55.6 \\
52.2 \\
51.9 \\
31.4\end{array}$ & $\begin{array}{l}59.0 \\
57.3 \\
57.9 \\
32.1\end{array}$ \\
\hline
\end{tabular}

${ }^{1}$ No varietal experiments were conducted in 1920.

2 Plat destroyed by storm.

The data presented in Table 12 show that Iowar was superior in yield to Albion and Richland as well as to the original Kherson. For the five years 1916, 1918, 1921, 1922, and 1923 it exceeded the average yield of Albion by 9.9 bushels per acre. The advantage over Kherson and Richland was less, however, being 4.1 and 3.9 bushels, respectively.

A statistical study ${ }^{4}$ of the yields of Iowar and Kherson for the six years 1916, 1917, 1918, 1921, 1922, and 1923 show odds of 2.36 to 1 in favor of Iowar. Odds as small as these are of no significance. While the affected yield of Iowar for 1917 has been used in this analysis the abnormally low yield of Kherson for 1921, for which there is no apparent explanation, also has been considered.

4 See footnote 2 , page 6 . 
The reaker stram of Iowar is indicated by the higher percentage of lodging. In bushel weight Iowar was practically the equal of Kherson and Albion, but it was slightly inferior to Richland.

\section{EXPERIMENTS ON IOWA FARMS}

The experiments at the Iowa station led to the belief that Iorar was a rariety destined to replace Albion in a rery large portion of

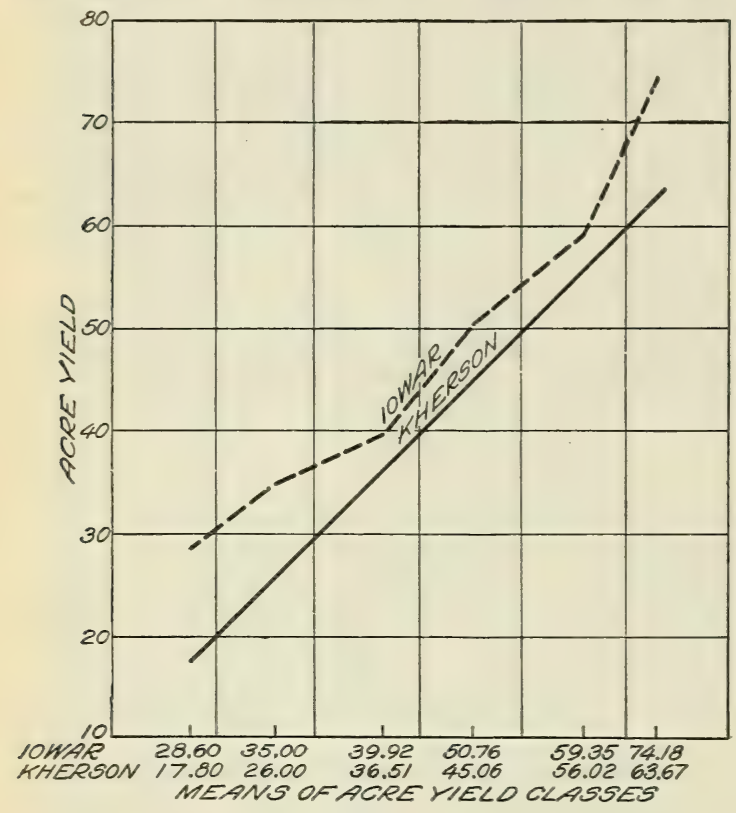

FIG. 10.-Diagram showing the mean acre rields (in bushels) of Iowar as compared with those of Kherson as a standard oat rariety in 33 trials on Iowa farms during the fire-rear period from 1919 to 1923 , inclusire

the State. Albion had been widely distributed both from the station and from commercial sources, and in the initial distribution and testing of Iowar it was requested that wherever conrenient Albion be used as the homegrown variety. During the five years from 1919 to 1923 , inclusive, Iowar was grown on 344 Iowa farms in comparison with home-grown rarieties. The number of experiments and the varieties included were as follows: Kherson 33, Albi on 153, Richland 42, Green Russian 31, and miscellaneous 85. The unknown home-grown varieties as well as those that were not grown in sufficient numbers to warrant separate comparison are grouped together under the heading of miscellaneous rarieties. A summary of the a rerage yields of these rarieties as compared with Iowar is given in Table 13.

TABLE 13.- Average acre yields of Iowar and other varieties of oats grown on 344 Iowa farms during the five-year period from 1919 to 1923 , inclusive

\begin{tabular}{|c|c|c|c|c|}
\hline \multirow[b]{2}{*}{ Home-grown variety } & \multirow[b]{2}{*}{$\begin{array}{l}\text { Number } \\
\text { of trials }\end{array}$} & \multicolumn{3}{|c|}{ Acre yields of grain (bushels) } \\
\hline & & Iowar & $\begin{array}{l}\text { Home- } \\
\text { grown } \\
\text { variety }\end{array}$ & Difference \\
\hline $\begin{array}{l}\text { Kherson } \\
\text { Albion } \\
\text { Richland } \\
\text { Green Russian } \\
\text { Miscellaneous varieties. }\end{array}$ & $\begin{array}{r}33 \\
153 \\
42 \\
31 \\
85\end{array}$ & $\begin{array}{l}49.81 \\
51.12 \\
52.93 \\
49.89 \\
46.47\end{array}$ & $\begin{array}{l}44.46 \\
44.31 \\
46.54 \\
45.24 \\
42.32\end{array}$ & $\begin{array}{l}5.35 \\
6.81 \\
6.39 \\
4.65 \\
4.15\end{array}$ \\
\hline Weighted average of all trials.... & 344 & 49.96 & 44.19 & 5.77 \\
\hline
\end{tabular}


In the 153 comparisons of Iowar with Albion there was an arerage gain of 6.81 bushels per acre in faror of Iowar. For the 42 and 33 comparisons with Richland and Kherson the arerage gains in faror of Iowar were 6.39 and 5.35 bushels, respectively. In the weighted average Iowar exceeded the home-grown varieties by 5.77 bushels per acre. Comparisons of the mean yields of Iowar with Kherson, Albion, and Richland, based on the indiridual data from farm tests which are not presented in this bulletin, are shown graphically in Figures 10, 11, and 12. The popularity and rapid distribution of Iowar are evidenced by the fact that, as previously stated, more than three - fourths of a million acres were devoted to it in Iowa alone in 1924.

\section{RATIO OF GRAIN TO}

The Iowar oat yields not only more grain but also more straw than other early strains like Albion and Richland. The average height of straw of the varieties, as given in Table 12, is evidence of this fact. In addition, data obtained during the five-year period from 1918 to 1922 , inclusive, when the Iowar oat was used on the soilfertility field at the Iowa station, show that it produced a higher proportion of

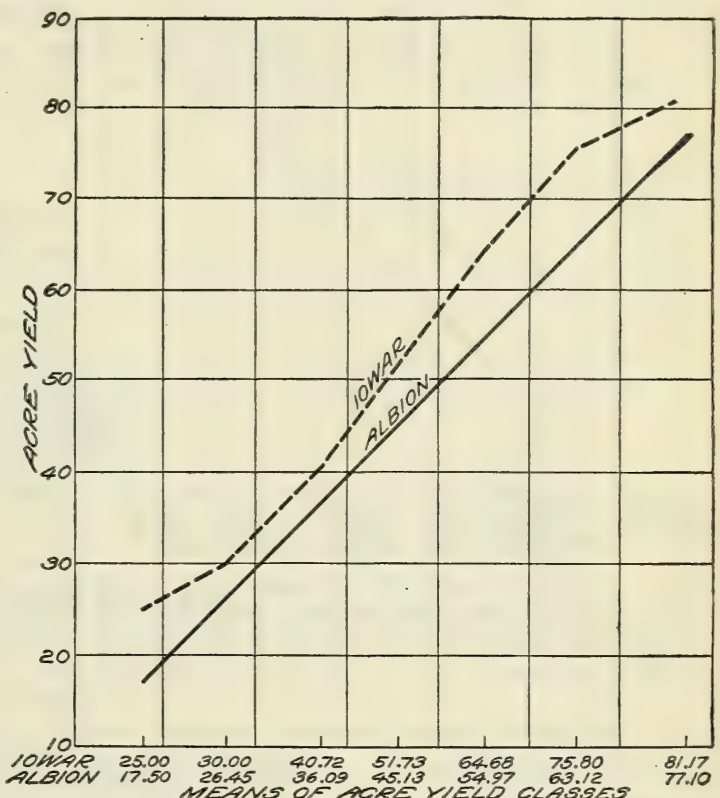

Frg. 11. Diagram showing the mean acre yields (in bushels) of Iowar as compared with those of Albion as a standard oat variety in 153 trials on Iowa farms during the five-year period from 1919 to 1923 , inclusive. straw to grain than the Albion on the same field during the preceding three-year period. The average acre yields and the proportion of grain to straw on 59 soil-fertility plats at the Iowa station for the five years from 1918 to 1922 , inclusive, were 1,638 pounds of grain and 1,612 pounds of straw, or about 50 per cent of each, respectively.

TABLE 14.-Annual and average acre yields (in bushels) of the Iowar oat grown in rate-of-seeding experiments at the Iou Agricultural Experiment Station during the five years 1917, 1918, 1920, 1921, and 1922

\begin{tabular}{|c|c|c|c|c|c|c|}
\hline \multirow[b]{2}{*}{ Year } & \multicolumn{6}{|c|}{ Rates of seeding per acre } \\
\hline & $\stackrel{2}{\text { bushels }}$ & $\begin{array}{c}21 / 2 \\
\text { bushels }\end{array}$ & $\begin{array}{c}3 \\
\text { bushels }\end{array}$ & $\begin{array}{c}31 / 2 \\
\text { bushels }\end{array}$ & $\begin{array}{c}4 \\
\text { bushels }\end{array}$ & $\begin{array}{c}41 / 2 \\
\text { bushels }\end{array}$ \\
\hline $\begin{array}{l}1917 \\
1918 \\
1920 \\
1921 \\
1922\end{array}$ & $\begin{array}{l}87.5 \\
55.6 \\
80.6 \\
39.8 \\
77.5 \\
\end{array}$ & $\begin{array}{l}91.2 \\
58.7 \\
79.4 \\
48.4 \\
83.1 \\
\end{array}$ & $\begin{array}{l}97.5 \\
53.7 \\
85.0 \\
51.6 \\
78.1 \\
\end{array}$ & $\begin{array}{r}102.4 \\
58.1 \\
86.9 \\
55.1 \\
80.0 \\
\end{array}$ & $\begin{array}{r}109.4 \\
55.0 \\
86.2 \\
57.6 \\
80.0 \\
\end{array}$ & $\begin{array}{r}110.0 \\
58.1 \\
78.7 \\
48.4 \\
83.1 \\
\end{array}$ \\
\hline A verage.... & 68.2 & 72.2 & 73.2 & 76.5 & 77.6 & 75.7 \\
\hline
\end{tabular}




\section{RATE-OF-SEEDING EXPERIMENTS}

The Iowar oat was grown in rate-of-seeding experiments during the fire years $1917,1918,1920,1921$, and 1922 , and the annual and arerage rields obtained in these experiments are given in Table 14.

The data presented in Table 14 show that the highest net arerage yields have been obtained from seeding at a rate of 4 bushels to the acre. This is a higher rate than has proved profitable with other

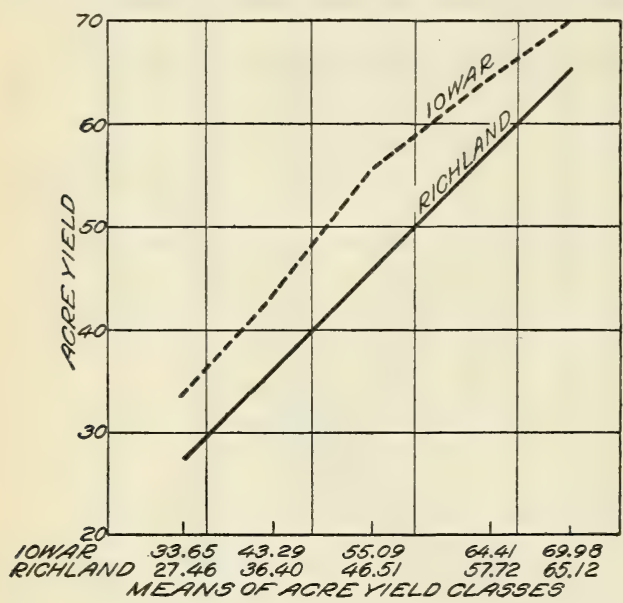

Fig. 12.-Diagram showing the mean acre yields (in bushels of Iowar as compared with those of Richland as a standard oat variety in 42 trials on Iowa farms during the five-year period from 1919 to 1923 , inclusive.

shown in Figure 13. The lact that the Green Russian variety has persisted in that section of Iorra indicates its excellent adaptability to existing soil and climatic conditions. For this reason the development of Iogren, a uniform high-yielding strain of the Green Russian type, seemed particularly desirable. The history of the Iogren and its description follow.

\section{HISTORY AND DESCRIPTION}

History.-The Iogren was dereloped from a single head of the Green Russian rariety obtained from $I T$. Eral, Pocahontas, Iowa. It was grown in a head row at the Iowa station in 1911 and was designated Iowa No. 840. The selection was grown in the nursery experiments in 1912, 1913, and 1914, and was advanced to the plat experiments in 1916. Iogren was first distributed to farmers in Iowa in 1922.

Description.-Early growth erect; plant midseason. Culms midsized, stiff, glabrous or slightly hairy at the nodes, 80 to 130 centimeters tall. Sheaths deep green, usially glabrous; culm leaves midsized, margins usually glabrous. Peduncle midsized, straight, well 
exserted. Panicle equilateral, drooping, midlong to long, wide, ovate; branches spreading to ascending, uppermost branch long, very drooping, distinct; rachis nodes 5 to 7 . Spikelets few to many, usually 2-flowered; kernels slender. Empty glumes 20 to 25 millimeters long, 5.5 to 7.5 millimeters wide, 9 to 10 veined. Lower lemma 16 to 20 millimeters long, yellow to yellowish white; upper end with greenish tinge at maturity; basal hairs few to absent; awns few to common, straight (nontwisted) to twisted and geniculate, 15 to 35 millimeters long. Upper lemma 11 to 16 millimeters, awnless. Rachilla segment midlong, usually glabrous.

Iogren is a rather tall midseason yellow variety, with midsized panicles. It usually can be recognized by its peculiarly long, drooping uppermost branches, and frequently by the greenish tinge or

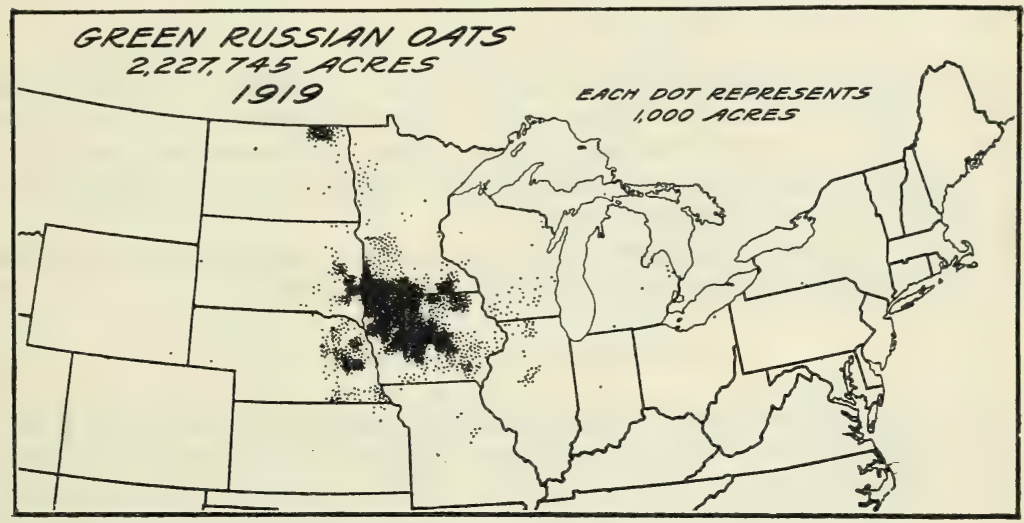

FIG. 13.-Outline map of a portion of the United States, showing distribution of the Green Russian oat in 1919

color of the upper end of the lemmas. The glumes at time or ripening are a creamy to greenish yellow color. It ripens at the same time as the parent variety, Green Russian. Under the environment of Ames, Iowa, the Iogren and a few other selections from the Green Russian parent have shown some resistance to stem rust. A panicle and spikelets of Iogren are shown in Figure 9.

\section{YIELDS OF IOGREN}

\section{EXPERIMENTS AT THE IOWA STATION}

Like the other pure lines previously described, Iogren was thoroughly tested at the Iowa Agricultural Experiment Station to determine its yielding power. The average dates of sowing and of ripening, height of plant, percentage of lodging, bushel weight, and the annual and average acre yields of Iogren and of the parent variety, Green Russian, grown in varietal experiments at the Iowa station for the seven years from 1916 to 1919, inclusive, and in 1921, 1922, and 1923 are shown in Table 15. 
TABLE 15.-Average dates of sowing and of ripening, height of plant, percentage of lodging, bushel ueight, and the annual and average acre yields of the Iogren and Green Russian oat varieties at the Iovoa Agricultural Experiment Station for the seven years from 1916 to 1919, inclusive, and in 1921, 1922, and $1923^{1}$

\begin{tabular}{|c|c|c|c|c|c|}
\hline Items of comparison & Iogren & $\begin{array}{l}\text { Green } \\
\text { Russian }\end{array}$ & Items of comparison & Iogren & $\begin{array}{c}\text { Green } \\
\text { Russian }\end{array}$ \\
\hline Average date sown. & Apr. 16 & Apr. 16 & 1919 & 50.0 & 45.9 \\
\hline $\begin{array}{l}\text { A verage date ripe } \\
\text { A verage height of plant, inches. }\end{array}$ & $\begin{array}{l}\text { July } 20 \\
40.9\end{array}$ & $\begin{array}{r}\text { July }_{40.1} 19 \\
\end{array}$ & 1921:- & 40.6 & 37.8 \\
\hline Average percentage of lodging & 2. 1 & 4.3 & 1923 & 84.7 & 74.7 \\
\hline $\begin{array}{l}\text { Acre yields of grain (bushels): } \\
\text { 1916 }\end{array}$ & 64.4 & 53.6 & Average & 64.2 & 56.3 \\
\hline $1917-\ldots$ & 62.5 & 50.0 & Average bushel weight & $0 \times 2$ & 00.0 \\
\hline 191 & 82.5 & 74.4 & _. & 32.0 & 31.7 \\
\hline
\end{tabular}

${ }^{1}$ No varietal experimentst were conducted in 1920.

According to the yield data presented in Table 15, during the seven years in which they have been compared Iogren has outyielded Green Russian by 7.9 bushels to the acre. A statistical study ${ }^{5}$ of this difference indicates odds of 1,999 to 1 that Iogren will outyield the parent variety, Green Russian.

In time of ripening Iogren is about one day later than Green Russian. In weight per bushel it is slightly superior.

\section{EXPERIMENTS ON IOWA FARMS}

Iogren was grown on Iowa farms in comparison with the parent variety (Green Russian), Iowar, and other miscellaneous varieties during the seasons of 1922 and 1923. The number of farm experiments in which Iogren was compared with other varieties was as follows: Green Russian 25, Iowar 35, and miscellaneous 51. A summary of the average yields of these experiments is given in Table 16.

TABLE 16.-Average yields of Iogren and other oat varieties grown on 111 Iowa farms in 1922 and 1923

\begin{tabular}{|c|c|c|c|c|}
\hline \multirow[b]{2}{*}{ Home-grown varieties } & \multirow[b]{2}{*}{$\underset{\text { trials }}{\text { Number of }}$} & \multicolumn{3}{|c|}{ Acre yield of grain (bushels) } \\
\hline & & Iogren & $\begin{array}{l}\text { Home- } \\
\text { grown } \\
\text { varieties }\end{array}$ & Difference \\
\hline $\begin{array}{l}\text { Green Russian } \\
\text { Iowar } \\
\text { Miscellaneous varieties }\end{array}$ & $\begin{array}{l}25 \\
35 \\
51\end{array}$ & $\begin{array}{l}\text { 49. } 91 \\
49.80 \\
48.66\end{array}$ & $\begin{array}{l}\text { 44. } 87 \\
\text { 48. } 09 \\
\text { 44. } 38\end{array}$ & $\begin{array}{l}\text { 5. } 04 \\
\text { 1. } 71 \\
\text { 4. } 28\end{array}$ \\
\hline Weighted average of all trials_. & 111 & 49.30 & 45.66 & 3. 64 \\
\hline
\end{tabular}

The data presented in Table 16 show an average difference of 5.04 bushels in favor of Iogren over the parent variety, Green Russian. For the 111 separate trials the average yield for Iogren was

${ }^{5}$ See footnote 2 , page 6. 
49.30 bushels, as compared with 45.66 bushels for the home-grown rarieties. The mean yields of the Iogren as compared with those of the Green Russian and Iowar, based on the indiridual data from the separate farm tests, are shown graphically in Figures 14 and 15 .

\section{RATE-OF-SEEDING}

\section{EXPERIMENTS}

During the years 1917 and 1920 to 1923 , inclusive, Iogren was grown in rate-ofseeding experiments. The annual and average yields are presented in Table 17.

From the data presented in Table 17 it is evident that the heavier rates of seeding produced the highest yields. Three bushels per acre has

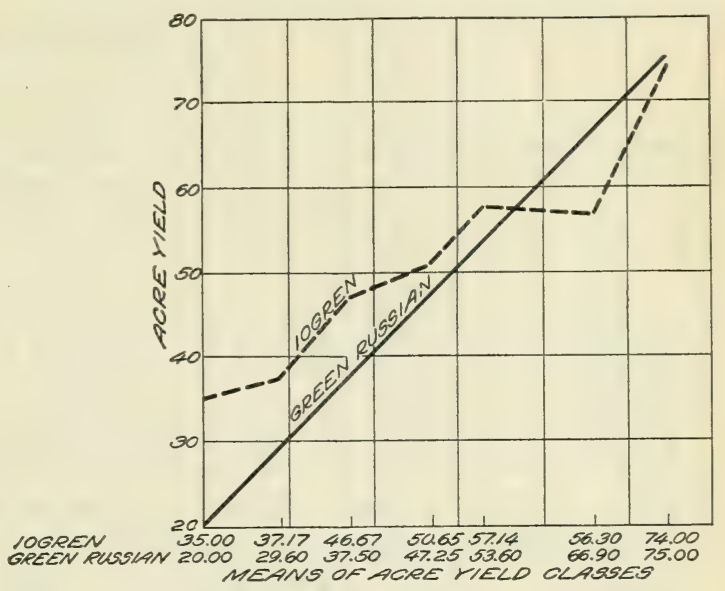

Fig. 14.-Diagram showing the mean acre yields (in bushels) of Iogren as compared with those of Green Russian as a standard oat variety in 25 trials on Iowa farms in 1922 and 1923

been considered the standard rate. In two of the five trials with Iogren this rate has given the highest vield. In the other three trials higher rates have given higher yields. The results so far obtained would indicate that the rate of seeding might profitably be increased to 4 bushels per acre.

TABLE 17.-Annual and average acre yields (in bushels) of the Iogren oat grown in rate-of-seeding experiments at the Iowa Agricultural Experiment Station during the five years, 1917 and 1920 to 1923, inclusive

Rate of seeding per acre

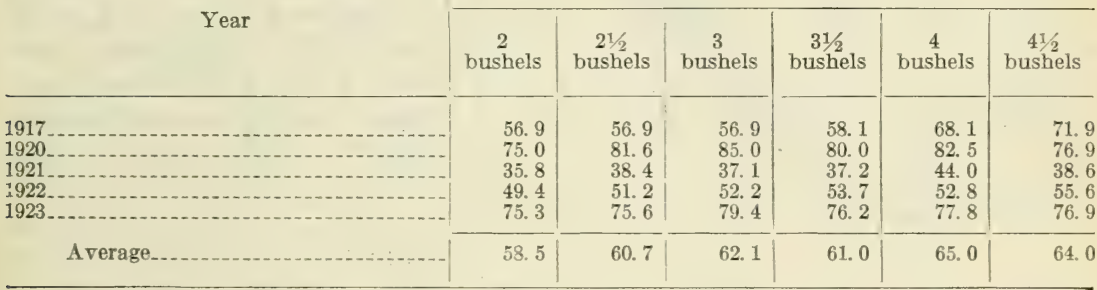

\section{YIELDS OF OTHER VARIETIES AT THE IOWA STATION}

To present more fully the behavior of the new oat rarieties, Albion, Richland, Iowar, and Iogren, described in this bulletin, it is desirable to show data on the yielding power of other early, midseason, and late rarieties at the Iowa Agricultural Experiment Station. Therefore, the annual and a verage yields of the rarieties which have been grown continuously since the inclusion of the Albion and Richland in the varietal tests at Ames in 1911 are shown in Table 18. 
TABLE 18.-Annual and average acre yields of Albion, Richland, Iowar, Iogren, and 11 other varieties of oats grown in cooperative experiments at the Iowa Agricultural Experiment Station during seven or more years of the 12-year period from 1911 to 1919 , inclusive, and in 1921, 1922, and 1923

\begin{tabular}{|c|c|c|c|c|c|c|c|c|c|c|c|c|c|c|}
\hline \multirow{3}{*}{ Group and variety } & \multicolumn{14}{|c|}{ Acre yields (bushels) } \\
\hline & \multirow[b]{2}{*}{1911} & \multirow[b]{2}{*}{1912} & \multirow[b]{2}{*}{1913} & \multirow[b]{2}{*}{1914} & \multirow[b]{2}{*}{1915} & \multirow[b]{2}{*}{1916} & \multirow[b]{2}{*}{1917} & \multirow[b]{2}{*}{1918} & \multirow[b]{2}{*}{1919} & \multirow[b]{2}{*}{1921} & \multirow[b]{2}{*}{1922} & \multirow[b]{2}{*}{1923} & \multicolumn{2}{|c|}{ Average } \\
\hline & & & & & & & & & & & & & $\begin{array}{c}1911 \text { to } \\
1919 \\
\text { and } \\
1921 \text { to } \\
1923\end{array}$ & $\begin{array}{l}1916 \text { to } \\
1919 \\
\text { and } \\
1921 \text { to } \\
1923\end{array}$ \\
\hline $\begin{array}{l}\text { Early yellow: } \\
\text { Kherson.- }\end{array}$ & & & & & & & & & & & & & & \\
\hline $\begin{array}{l}\text { Knerson--- } \\
\text { Richland.- }\end{array}$ & $\begin{array}{l}38.1 \\
44.8\end{array}$ & $\begin{array}{l}65.6 \\
83.7\end{array}$ & $\begin{array}{l}62.8 \\
55.6\end{array}$ & $\begin{array}{l}55.3 \\
62.8\end{array}$ & $\left|\begin{array}{l}49.1 \\
59.3\end{array}\right|$ & \begin{tabular}{|l|}
53.8 \\
53.6
\end{tabular} & \begin{tabular}{|l|}
65.0 \\
64.3
\end{tabular} & $\begin{array}{l}62.5 \\
55.6\end{array}$ & $\begin{array}{l}41.9 \\
47.5\end{array}$ & $\begin{array}{l}25.9 \\
37.2\end{array}$ & $\begin{array}{l}67.8 \\
65.0\end{array}$ & \begin{tabular}{|l|}
78.7 \\
78.1
\end{tabular} & $\begin{array}{l}55.5 \\
59.0\end{array}$ & $\begin{array}{l}56.5 \\
57.3\end{array}$ \\
\hline $\begin{array}{l}\text { Early white: } \\
\text { Albion. }\end{array}$ & & & & & & & & & & & & & & \\
\hline Álbion. & 40.6 & 53.7 & 63.7 & 55.6 & 41.6 & |46.1 & 73. 7 & 48.7 & 32.2 & 37.4 & 58.7 & 68.7 & 51.7 & 52.2 \\
\hline $\begin{array}{l}\text { 10war.... } \\
\text { Daubeney }\end{array}$ & 31.0 & 71.2 & 50.3 & 48.1 & 50.9 & $\begin{array}{l}56.7 \\
52.4\end{array} \mid$ & $\begin{array}{l}57.5 \\
81.9\end{array}$ & $\begin{array}{l}62.5 \\
64.3\end{array}$ & 50.3 & $\begin{array}{l}41.2 \\
19.4\end{array}$ & $\mid \begin{array}{l}60.6 \\
62.5\end{array}$ & \begin{tabular}{|l|}
87.8 \\
73.4
\end{tabular} & 54.6 & $\begin{array}{r}{ }^{2} 61.1 \\
57.7\end{array}$ \\
\hline Early Champion. & 35.0 & 48.1 & 50.6 & 48.4 & 42.2 & 48.7 & 68.1 & 43.7 & 25.3 & 28.4 & 50.9 & 72.7 & 46.8 & 48.3 \\
\hline $\begin{array}{l}\text { Early red: } \\
\text { Burt } \\
\text { Red } \mathrm{Ru}\end{array}$ & 40.6 & 60.6 & 52.1 & 45.6 & 54.7 & 55.3 & 79.4 & 42.5 & 40.0 & 25.0 & 57.8 & 76.6 & 52.5 & 53.8 \\
\hline $\begin{array}{l}\text { (Texas Red) }{ }^{3} \text {..... } \\
\text { Midseason white: }\end{array}$ & 5.9 & 68.7 & 49.1 & 44.7 & 54.4 & 51.2 & 66. 2 & 88.1 & 50.3 & 23.4 & 51.9 & 44.1 & 49.8 & 53.6 \\
\hline Silvermine & 36. 3 & 81.9 & 60.3 & 46.8 & 55.2 & 51.7 & 71.2 & 70.0 & 35.0 & 28.4 & 57.5 & 75.6 & 55.8 & 55.6 \\
\hline $\begin{array}{l}\text { Green Russian } \\
\text { Iogren }\end{array}$ & 31.8 & 83.7 & 53.4 & 45.7 & 57.6 & \begin{tabular}{|l|}
53.6 \\
64.4
\end{tabular} & $\begin{array}{l}50.0 \\
62.5\end{array}$ & $\begin{array}{l}74.4 \\
82.5\end{array}$ & $\begin{array}{l}45.9 \\
50.0\end{array}$ & $\begin{array}{l}37.8 \\
40.6\end{array}$ & $\begin{array}{l}57.5 \\
65.0\end{array}$ & $\begin{array}{l}74.7 \\
84.7\end{array}$ & 55.5 & 56. 3 \\
\hline Early Gothland & 23.6 & 80.0 & 62.8 & 43.1 & 60.7 & 50.0 & 53.7 & 90.6 & $(a)$ & 30.9 & 52.2 & 70.6 & & $\begin{array}{r}258.0 \\
258.2\end{array}$ \\
\hline $\begin{array}{l}\text { Swedish Select } \\
\text { Midseason black: }\end{array}$ & 25.5 & 75.0 & 50.6 & 37.6 & 44.8 & 43.0 & 63.7 & 65.0 & 23.1 & 35.6 & 62.5 & 73.7 & 50.0 & 52.4 \\
\hline $\begin{array}{l}\text { Midseason black: } \\
\text { Joanette }\end{array}$ & 23.9 & 88.7 & 50.2 & 43.7 & 60.6 & 52.6 & 66.9 & 81.9 & 62.2 & 45.3 & 55.3 & 66.6 & 58.2 & 61.5 \\
\hline $\begin{array}{l}\text { Late white (side): } \\
\text { White Tart a r } \\
\text { (White Russian).- }\end{array}$ & 19.8 & 83.1 & 46.6 & 44.4 & 52.3 & 41.4 & 35.0 & 73.4 & $=21.2$ & 38.1 & 42.8 & 50.0 & 45.7 & 43.1 \\
\hline
\end{tabular}

1 Plat destroyed by storm.

2 Average for 1916, 1917, 1918, 1921, 1922, and 1923.

3 Red Rustproof under the environment of Ames ripens later than midseason but earlier than late oats.

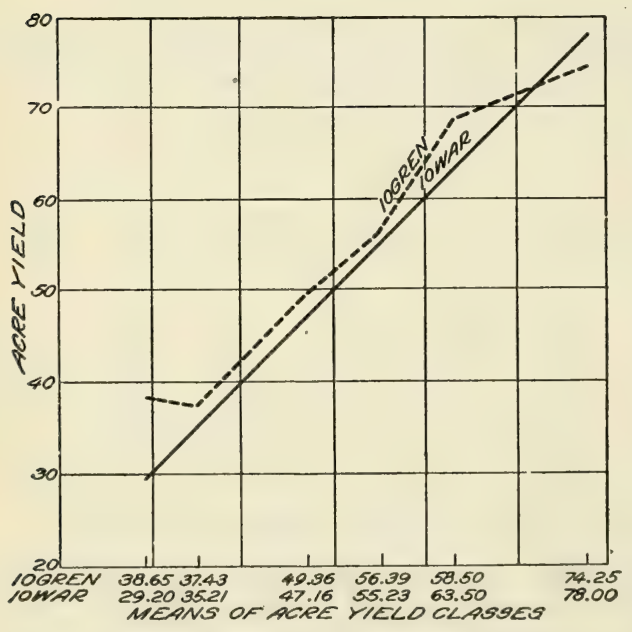

Fig. 15-Diagram showing the mean acre yields (in bushels) of Iogren as compared with those of Iowar as a standard oat variety in 35 trials on Iowa farms in 1922 and 1923
Reference to the data presented in Table 18 shows that of the 12 varieties grown continuously for the 12 years from 1911 to 1919 , inclusive, and in 1921, 1922, and 1923, Richland produced the highest arerage yield, with the midseason black oat, Joanette, a close second. Albion was exceeded in yield by seven varieties. Of the midseason varieties, Silvermine and Green Russian were superior, their average yield being practically the same as that of Kherson. During the seven years from 1916 to 1919 , inclusive, and in 1921, 1922, and 
1923, Iogren was the highest yielder, Joanette being second and Iowar third. This result demonstrates the value of Iowar and Iogren for growing in the Corn Belt.

\section{YIELDS OF ALBION, RICHLAND, AND IOWAR OATS OUTSIDE OF IOWA}

The adaptation and yielding power of these new varieties in States near Iowa is of interest. Conditions within a rather distinct area extending from western Ohio through Indiana, Illinois, and including practically all of Iowa are quite similar, this being the central portion of the Corn Belt, and it was believed that these new varieties might find a place elsewhere in this area.

The Office of Cereal Investigations in 1916 distributed Albion and Richland to the various field stations in the Great Plains, the western Great Basin, and the coast areas where cooperative experiments with oats were being conducted. Iowar and Iogren likewise have been distributed in later years. In addition, the various State agricultural experiment stations placed these improved sorts in their varietal experiments. As a result considerable data are now available, particularly for Albion and Richland, which show their performance in comparison with older standard varieties.

Through the courtesy of the agronomy departments of the State agricultural experiment stations it is possible to present a rather complete resume of the average yields of these improved varieties in comparison with the yields of parent and of other standard varieties in surrounding Corn Belt and other States.

The State stations which furnished data are the following: Ohio, Indiana, Illinois, Michigan, Wisconsin, Minnesota, Missouri, North Dakota, Nebraska, and Kansas. Data also have been summarized from the annual reports of the following stations and substations at which the Office of Cereal Investigations is now or was formerly cooperating: Brookings, Highmore, and Newell, S. Dak.; Dickinson and Williston, N. Dak.; Moccasin, Mont.; Cheyenne and Sheridan, Wyo.; Akron, Colo.; Aberdeen, Idaho; Nephi, Utah; and Moro, Oreg.

A summary of data obtained at 22 experiment stations in the Corn Belt, Great Plains, western Great Basin, and coast areas of the United States on the average yield of Albion, Richland, and Iowar, the parent varieties Kherson and Sixty-Day, and nine other standard varieties of oats is presented in Table 19. In a few instances it has been necessary to substitute the yields of identical or similar varieties, such cases being indicated. 


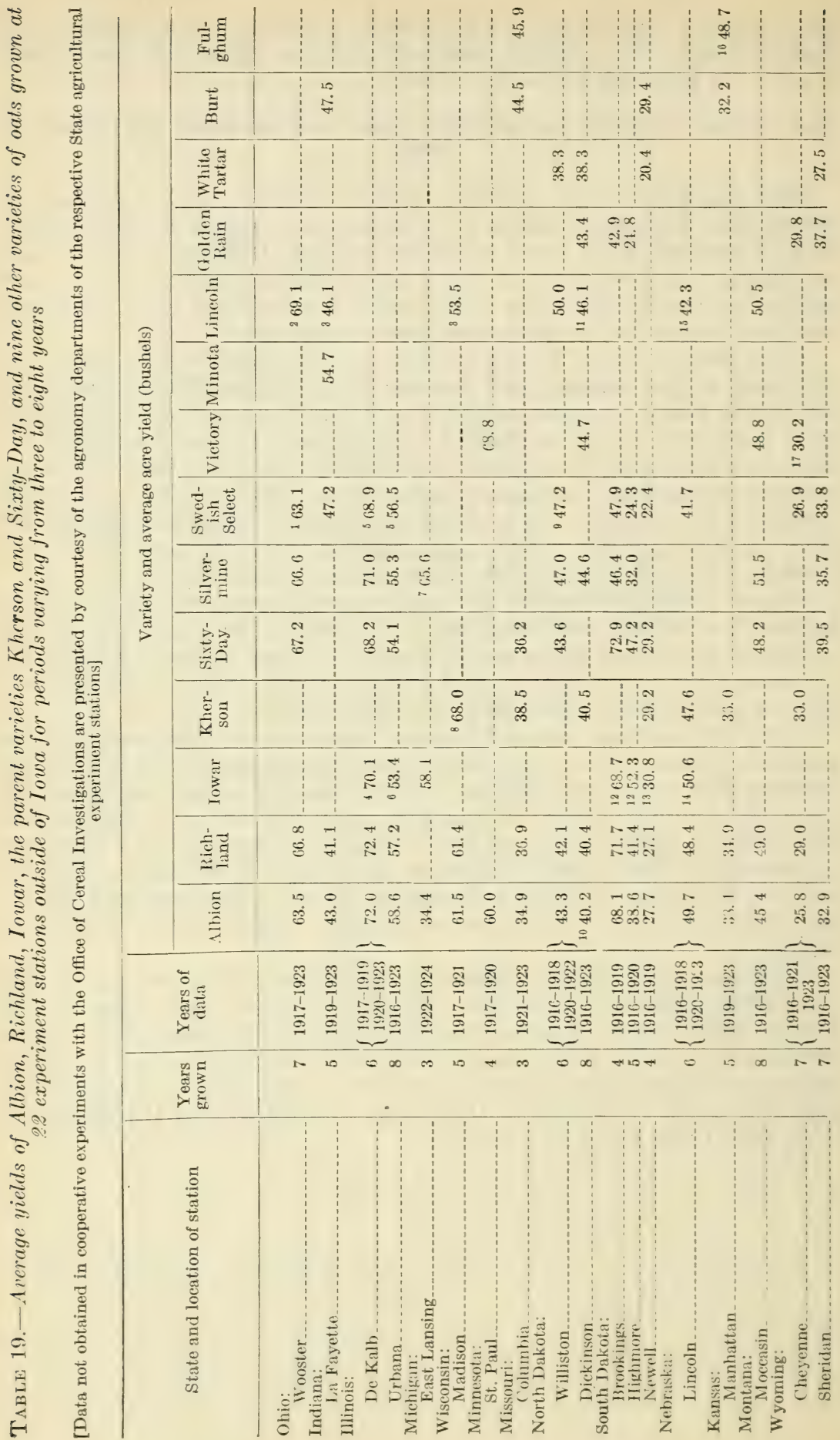



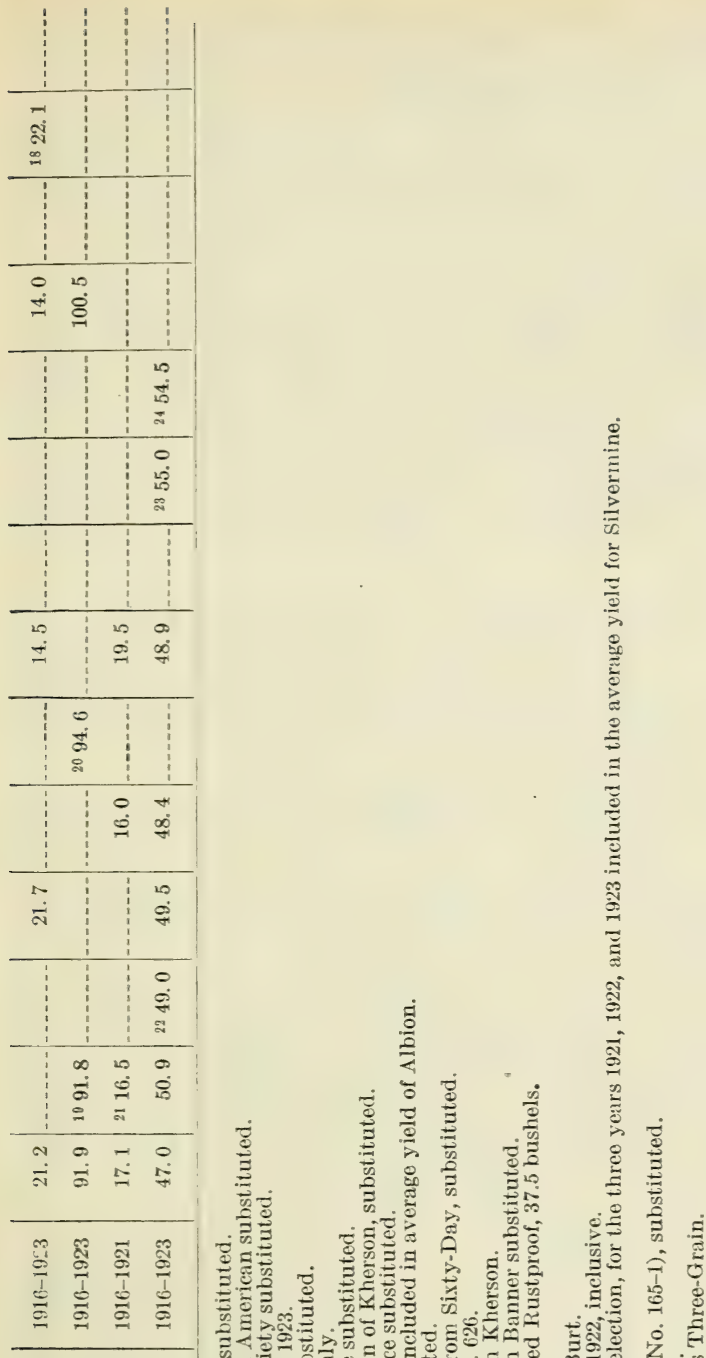
के

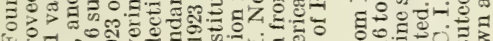

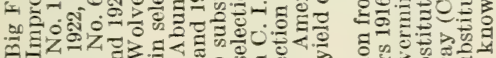
$\lambda>0-$ a

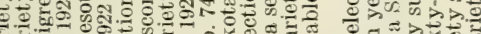

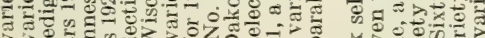
Q

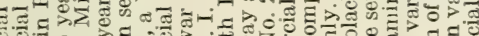

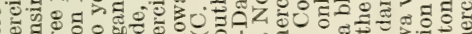

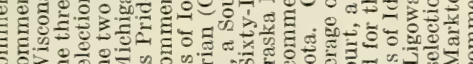

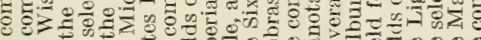

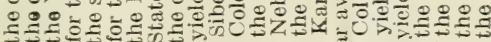

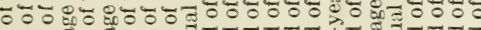

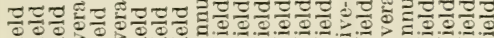

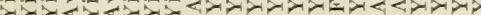

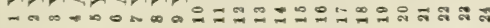


Reference to Table 19 shows that in general the selections Albion, Richland, and Iowar slightly outyielded the parent varieties, Kherson and Sixty-Day. ${ }^{6}$ As a consequence, where early varieties of this type are most satisfactory, these improved strains are preferable to the parent varieties. In addition to their slightly higher yielding power these selected strains are decidedly more uniform and usually produce grain of better quality, the white kernels of the Albion and Iowar being also particularly desirable.

The data also show rather definitely the range of adaptability of Albion, Richland, and Iowar both by their average yields and by the average yields of the parent varieties, Kherson and SixtyDay. At Wooster, Ohio, the original Sixty-Day outyields both Albion and Richland, the difference between Richland and the parent variety being so slight, however, that it can not be considered as significant. At this station Lincoln, a midseason white oat, has produced on the average 1.9 bushels per acre more than the SixtyDay.

Neither Albion nor Richland compares favorably in yield with such midseason varieties as Swedish Select, Lincoln, and Minota at La Fayette, Ind. At this station Burt, an early red oat, also has decidedly outyielded these improved Kherson strains. Unfortunately, the parent varieties, Kherson and Sixty-Day, were not grown at La Fayette during the period covered by these data.

Albion and Richland have shown in Illinois a rather consistent superiority to the parent variety, Sixty-Day, as well as to the best midseason oats, such as Silvermine, Swedish Select, and Lincoln. These two varieties apparently are well adapted for growing in central and northern Illinois.

Albion and Iowar can not compete in Michigan in yield with such midseason varieties as Wolverine and Worthy.

At Madison, Wis., States Pride (Wisconsin Pedigree No. 7), a tall yellow selection of Kherson, has outyielded Albion and Richland by about 6.5 bushels per acre during the five years from 1917 to 1921 , inclusive. Both the Iowa selections have decidedly outyielded the Lincoln variety, a midseason white oat.

At St. Paul, Minn., Albion has been inferior in yield to Victory, one of the best midseason varieties for that State. Albion can be recommended in Minnesota only where an early variety is desirable as a nurse crop or because of some other similar reason.

At Columbia, Mo., both the Burt and Fulghum, early red varieties, have decidedly outyielded both Albion and Richland as well as the parent varieties, Kherson and Sixty-Day.

In North Dakota, at both Dickinson and Williston, there has been essentially no difference in yield between the Iowa selections and the parent varieties. In this State the midseason varieties, Silvermine, Lincoln, Swedish Select, Victory, etc., outyield the early varieties and are preferable.

Albion and Richland have been slightly inferior in yield to the parents, Kherson and Sixty-Day, at Brookings, Highmore, and Newell, S. Dak. These early oats as a group are much superior in

${ }^{B}$ For a history of the introduction of Kher:on and Sixty-Day oats into the United S'tates see Department Bulletin 823, Experiments with Kherson and Sixty-Day Oats, by C. W. Warburton and T. IR. Stanton. Botanically the Kherson and Sixty-Day are identical varieties. White-kerneled strains have been selected from both. 
yielding ability to midseason varieties, such as Silvermine and Swedish Select, and are to be highly recommended for that State.

At Lincoln, Nebr., Albion and Richland have both slightly outyielded the parent variety, Kherson, and therefore are well adapted for growing in that State. Nebraska No. 21, a strain morphologically identical with Albion, has been equally satisfactory.

At Manhattan, Kans, Kanota, a strain of Fulghum, has been decidedly superior in yield to the Iowa selections. This variety is being recommended by the Kansas station.

At Moccasin, Mont., the results are similar to those in North Dakota. Silvermine, the highest yielding variety, however, has exceeded the yield of Richland by only 2.5 bushels per acre. Richland, in turn, has outyielded the parent variety, Sixty-Day, only slightly.

In Wyoming, at Cheyenne, both Albion and Richland have produced lower average yields than Kherson. The early varieties as a group, however, are equal in yield to the best midseason varieties, such as Victory, Ligowa, and Golden Rain. At Sheridan, Wyo., Albion has been exceeded in yield by the midseason varieties, Silvermine and Swedish Select, but the parent variety, Sixty-Day, has produced the highest yield of all.

In Colorado the results at Akron show Albion to be practically identical in yield with the Kherson parent. Burt is very slightly superior to both these varieties, although not significantly so.

Under irrigation at Aberdeen in southern Idaho the early varieties can not compete with Golden Rain, Idamine, and other later maturing oats.

At Nephi, Utah, Albion has outyielded the Sixty-Day parent over a six-year period by only 1.1 bushels. Swedish Select, a midseason white oat, has outyielded Albion by 2.4 bushels and is preferable to any of the earlier varieties.

At Moro, Oreg., there has been little difference in the yields of Albion and Richland and those of the parent varieties, Kherson and Sixty-Day. Such midseason varieties as Markton and Three-Grain, however, produce higher yields than any of the early types and therefore are to be recommended.

\section{SUMMARY}

In this bulletin there are described four oat varieties, Albion, Richland, Iowar, and Iogren, which have been developed cooperatively by the Iowa Agricultural Experiment Station and the Office of Cereal Investigations of the Bureau of Plant Industry, United States Department of Agriculture.

Albion was developed from a single plant selected from Kherson in 1906. Owing to the demand for an early variety with white kernels, even though Albion did not show superiority in yield to Kherson, its distribution was begun in 1913 . 'The variety immediately became popular, and it was estimated that nearly 1,500,000 acres were grown in the Corn Belt in 1919, while in 1924 almost this acreage was grown in Iowa alone.

Richland, an early yellow oat, is a companion strain of Albion and has about the same history. It was selected from Kherson in 1906, primarily because of its short, rather stiff culm. It was first distributed in 1914. In yielding power it is superior to both Kherson 
and Albion, and because of its short straw it is especially recommended for growing on rich soils where taller varieties frequently cause partial loss of the crop by lodging.

Iowar was selected in 1911 from Kherson and differs from Albion in having a taller culm and in being a little later in maturity. It is superior in yielding power to Kherson and Albion. It was first distributed in 1919. Iowar is the most promising of the three early varieties here discussed and already has attained a wide distribution in Iowa and adjoining States. The variety probably will replace Albion to a considerable extent because of its higher yielding ability and its taller straw.

Iogren, a selection from Green Russian, was increased from an original plant selection made in 1910. The variety was first distributed to farmers in 1922. Iogren has been markedly superior in yield to the parent, Green Russian, and it is believed will ultimately largely replace that variety in northern Iowa. Of all the varieties grown in the experiments at Ames, Iogren has been the highest yielder.

Albion, Richland, and Iowar have been most promising in States other than Iowa in those sections where the parent sorts, Kherson and Sixty-Day, have been the leading varieties. Since in such areas the selections usually slightly outyield the parent varieties, they may profitably be substituted where Kherson or Sixty-Day is grown. 


\section{ORGANIZATION OF THE UNITED STATES DEPARTMENT OF AGRICULTURE}

September 15, 1925

Secretary of Agriculture

Assistant Secretary

Director of Scientific Work

Director of Regulatory Work

Director of Extension Work

Director of Information

Director of Personnel and Business $A d$. ministration

Solicitor.

Weather Bureau

Bureau of Agricultural Economics

Bureau of Animal Industry

Bureau of Plant Industry

Forest Service.

Bureau of Chemistry

Bureau of Soils.

Bureau of Entomology

Bureau of Biological Survey

Bureau of Public Roads.

Bureau of Home Economics

Bureau of Dairying

Fixed Nitrogen Research Laboratory-

Office of Experiment Stations.

Office of Cooperative Extension Work

Library

Federal Horticultural Board

Insecticide and Fungicide Board

Packers and Stockyards Administration

Grain Futures Administration
W. M. JARDINE.

R. W. DUNLAP.

Walter G. Campbell.

C. W. Warburton.

Nelson Antrim Crawford.

W. W. STOCkberger.

R. W. Williams.

Charles F. Marvin, Chief.

Thomas P. Cooper, Chief.

JoHn R. Mohler, Chief.

William A. Taylor, Chief.

W. B. Greeley, Chief.

C. A. Browne, Chief.

Minton Whitney, Chief.

L. O. Howard, Chief.

E. W. Nelson, Chief.

Thomas H. MacDonald, Chief.

Louise Stanley, Chief.

C. W. Larson, Chief.

F. G. Cottrell, Director.

E. W. Allen, Chief.

C. B. Sмiтн, Chief.

Claribel R. Barnett, Librarian.

C. L. Marlatt, Chairman.

J. K. HAYWOOD, Chairman.

JoHN T. CAINe, in Charge.

J. W. T. Duvel, in Charge.

This bulletin is a contribution from

Bureau of Plant Industry

Office of Cereal Investigations
William A. Taylor, Chief.

Carleton R. Ball, Senior Agronomist, in Charge.

ADDITIONAL COPIES

OF THIS PUBLICATION MAY BE PROCURED FROM

THE SUPERINTENDENT OF DOCUMENTS

GOVERNMENT PRINTING OFFICE

WASHINGTON, D. C.

AT

10 CENTS PER COPY 
